\title{
Synthesis of isotopically labeled P-site substrates for the ribosomal peptidyl transferase reaction
}

\author{
Minghong Zhong ${ }^{1}$ and Scott A. Strobel ${ }^{1,2}$ \\ Scott A. Strobel: scott.strobel@yale.edu \\ ${ }^{1}$ Department of Molecular Biophysics and Biochemistry, Yale University, New Haven, Connecticut \\ 06520-8114 \\ 2Department of Chemistry, Yale University, New Haven, Connecticut 06520-8114
}

\section{Abstract}

\begin{abstract}
Isotopomers of the ribosomal P-site substrate, the trinucleotide peptide conjugate CCA-pcb, ${ }^{1}$ have been designed and synthesized in 26-350020steps. These include individual isotopic substitution at the $\alpha$-proton, carbonyl carbon, and carbonyl oxygen of the amino acid, the $\mathrm{O} 2$ ' and $\mathrm{O} 3$ ' of the adenosine, and a remote label in the $\mathrm{N} 3$ and $\mathrm{N} 4$ of both cytidines. These isotopomers were synthesized by coupling cytidylyl-(3'5')-cytidine phosphoramidite isotopomers, as the common synthetic intermediates, with isotopically substituted A-Phe-cap-biotin (A-pcb). The isotopic enrichment is higher than $99 \%$ for ${ }^{1-13} \mathrm{C}$ (Phe), $2-{ }^{2} \mathrm{H}$ (Phe), and 3,4- ${ }^{15} \mathrm{~N}_{2}$ (cytidine), 93\% for $2^{\prime} / 3^{\prime}-{ }^{18} \mathrm{O}$ (adenosine), and $64 \%$ for $1{ }^{18} \mathrm{O}(\mathrm{Phe})$. A new synthesis of highly enriched $\left[1^{-1}{ }^{18} \mathrm{O}_{2}\right]$ phenylalanine has been developed. The synthesis of $\left[3^{\prime}-{ }^{18} \mathrm{O}\right]$ adenosine was improved by Lewis acid aided regioselective ring opening of the epoxide and by an economical $\mathrm{S}_{\mathrm{N}} 2-\mathrm{S}_{\mathrm{N}} 2$ method with high isotopic enrichment (93\%). Such substrates are valuable for studies of the ribosomal peptidyl transferase reaction by complete kinetic isotope effect analysis and of other biological processes catalyzed by nucleic acid related enzymes, including polymerases, reverse transcriptases, ligases, nucleases, and ribozymes.
\end{abstract}

\section{Introduction}

The catalytic mechanism of peptide bond formation by the ribosome is an area of ongoing research. Several aspects of the reaction mechanism are well-established. ${ }^{2}$ The reaction uses two substrate tRNAs, an aminoacyl-tRNA that binds to the A site and a peptidyl tRNA that binds to the P site. The reaction involves aminolysis of the P-site ester by the A-site $\alpha$-amino group. Relative to the rate in solution, the peptidyl transferase center of the ribosome provides a rate enhancement of approximately $10^{7}$ fold, a contribution that has been largely attributed to entropy. ${ }^{3}$ The nascent peptide in the $\mathrm{P}$ site and the amino acid in the A site are both linked via an ester to the 3'-O of the terminal nucleoside of the tRNA, A76. The 2'-OH vicinal to the $\mathrm{P}$-site ester is essential for the reaction. Deletion or alteration of this functional group results in a complete loss of peptidyl transferase activity ( $>10^{6}$ fold loss of activity). ${ }^{4}$ This contribution is significantly greater than that made by any of the rRNA nucleotides within the active site, though the 2'-OH of A2451 also makes an important contribution. ${ }^{5}$ The ribosome aligns the two substrates such that reaction proceeds through a chiral transition state with an $\mathrm{S}$ stereochemistry. ${ }^{6}$ This configuration places the critical A76 2'-OH between the $\alpha$-amino

Correspondence to: Scott A. Strobel, scott. strobel@yale.edu.

Supporting Information Available. General experimental procedures, experimental details and synthetic procedures for compounds 2b, 3b, 5b-8b, 22-24e and f, 27, 29a, 29b, 30-31a, d-h, 34a, d-h, 35a-h; ${ }^{1} \mathrm{H}$ NMR for new compounds (11- 15, 27, 29b, and 31g), and $\mathrm{H}-15 \mathrm{~N}$ HMBC for compounds $6 \mathrm{~b}$ and $\mathbf{9 b}$; and mass spectra of $\mathbf{1 a - h}, \mathbf{9 b}, \mathbf{1 6 f}, \mathbf{2 8 a}, \mathbf{3 4 e}$, and $34 \mathbf{f}$. This material is available free of charge via the Internet at http://pubs.acs.org 
nucleophile and the 3'-O leaving group. Possible roles for this hydroxyl in proton transfer from the $\alpha$-amine to the 3'-O have been proposed. 7(c, i, k)

Although the essential contributors to the reaction have been largely defined, both biochemically and structurally, several substantially different mechanisms have been drawn to explain these observations. ${ }^{7,8}$ One model assumes a mechanism equivalent to that observed in solution in which the reaction proceeds through a zwitterionic $\mathrm{T}^{ \pm}$intermediate followed by deprotonation to a $\mathrm{T}^{-}$intermediate that is then resolved into products.7( $\left.\mathrm{a}, \mathrm{b}\right)$ It is suggested that the A76 2'-OH could accept the proton from the $\alpha$-amino group. A second alternative involves resolution of the $\mathrm{T}^{ \pm}$intermediate directly to products by the simultaneous transfer of a proton from the amine, through the $\mathrm{A} 762^{\prime}-\mathrm{OH}$ to the 3'-O leaving group as the $\mathrm{C}-\mathrm{O}$ bond is broken.7(c, i) A third suggestion, which has appeared in several reviews, involves the simultaneous $\mathrm{N}-\mathrm{C}$ bond formation with $\mathrm{C}-\mathrm{O}$ bond cleavage coupled to proton transfer through the 2'-OH.7 (d-g) This mechanism does not involve a tetrahedral intermediate. Other mechanistic proposals have also been made that invoke additional intermediates and transition states.7(h, j)

In order to understand the role the ribosome plays in promoting the peptidyl transferase reaction, it is essential to characterize the reaction mechanism. The most powerful approach for transition state characterization is kinetic isotope effect (KIE) analysis in which heavy isotopes are introduced at atoms expected to have altered bonding in the transition state. By measuring and analyzing the small differences in reaction rate that result from isotopic substitution, it is possible to characterize the nature of the chemical transition state.

Toward this goal we prepared an A-site substrate in which the $\alpha$-amino group was ${ }^{15} \mathrm{~N}$ substituted and used this substrate to measure a KIE of 1.009 for this substitution. ${ }^{9}$ This analysis provided evidence that chemistry is at least partially rate limiting in the modified fragment reaction between CCA-pcb and CCPmn catalyzed by 50S ribosomes. The magnitude of the ${ }^{15} \mathrm{~N}$ KIE suggests either that the transition state is early, with little N-C bond order, or that there is significant deprotonation of the amine in the transition state. It is impossible to distinguish these possibilities or to speculate on the nature of other changes in the reaction coordinate based upon this single measurement. Our goal is to expand the KIE measurements to include substitutions at other atoms involved in the aminolysis reaction, all of which are located within the P-site substrate. This necessitates that various isotopic substitutions be introduced into the substrate CCA-pcb.

The P-site substrate contains the last three nucleotides at the 3'-end of the tRNA (CCA) linked to a peptidyl mimic (pcb) by an ester linkage. Kinetic isotope effects of P-site atoms that are directly or closely involved in the reaction are expected to provide specific information about the reaction mechanism (Fig. 1, X1 = N). ${ }^{10}$ For example, the carbonyl carbon is directly involved in peptide bond formation, and the ${ }^{13} \mathrm{C}$ isotope effect at this position is always normal (>1.00) in solution aminolysis reactions with a magnitude as large as 1.04 (a 4\% KIE). This substitution provides information about the extent of $\mathrm{N}-\mathrm{C}$ bond formation in the transition state. Deuterium substitution at the adjacent $\alpha-\mathrm{H}$ is expected to result in an inverse $\mathrm{KIE}\left(\mathrm{k}^{\mathrm{D}}>\mathrm{k}^{\mathrm{H}}\right)$, and its magnitude (reported to be between $0-11 \%$ ) will define the orbital hybridization at the reaction center carbon, with large KIEs correlating to $\mathrm{sp}^{3}$ hybridization of the tetrahedral intermediate and small KIEs to $\mathrm{sp}^{2}$ hybridization of a concerted mechanism. The primary isotope effect of the carbonyl oxygen should be normal, and its magnitude should also correlate with its bonding characteristics and environment, such as its bond order with the reaction center carbon in the transition state (TS). The kinetic isotope effect of the leaving group $\left({ }^{18} \mathrm{k}_{\mathrm{lg}}\right)$ for the ester linkage can further define the chemical mechanism of this catalyzed reaction. The ${ }^{18} \mathrm{k}_{\mathrm{lg}}$ for the alkaline hydrolysis of methyl formate, where formation of tetrahedral intermediate is rate limiting, is $0.9 \%$; while the hydrazinolysis reaction has a KIE of $6.2 \%$. 
This isotope effect provides valuable information about the degree of $\mathrm{C}-\mathrm{O} 3$ ' bond cleavage in the transition state. The value of the isotope effect at the $\mathrm{O} 2$ ' should correlate with its catalytic role and define the bonding details of this atom as a possible proton shuttle.

In the KIE study of the A-site $\alpha$-amine we used a competition method in which the heavy and the light isotopomer were mixed together and the change in substrate ratio was monitored using mass spectroscopy with a remote label. This approach necessitates that isotopic substitutions are also made at a site distant from the reactive groups. For this purpose we have selected the $\mathrm{N} 3$ and $\mathrm{N} 4$ nitrogens of the two cytidines for ${ }^{15} \mathrm{~N}$ substitution (Fig. 1). This provides a convenient mass change of four Daltons that is expected to fully separate the light and heavy substrate peaks on the mass spectrometer.

Isotopically labeled nucleosides, nucleotides, and their polymers (RNA and DNA) have potential applications in exploring the mechanistic details of fundamental biological processes such as protein synthesis, DNA and RNA synthesis, mRNA posttranscriptional modifications and processing, and formation of small RNAs, as shown in recent reviews on biological kinetic isotope effects. ${ }^{11}$ However, there are few reports of this kind of synthetic efforts, and the probes that are used are usually prepared by enzymatic methods on small scales. We have reported the solid phase synthesis of CCPmn with ${ }^{15} \mathrm{~N}$ substitutions at the $\alpha$-amine of puromycin and the $\mathrm{N} 3$ and $\mathrm{N} 4$ of cytidine. ${ }^{12}$ However, this synthetic strategy, as well as other routine synthetic methods for oligonucleotides, cannot be applied to the synthesis of CCA-pcb isotopomers for the following reasons. First, the 3 '-ester linkage is highly labile and will not survive the coupling reactions and final basic deprotection steps; second, the chirality of the amino acids is sensitive to the basic conditions used in oligonucleotide synthesis. Therefore, we have developed a compatible solution phase method to synthesize these isotopically labeled P-site substrates. ${ }^{1}$

We have reported the synthesis of CCA-pcb in two different schemes by phosphoramidite chemistry, using acid-labile 2'-O-bis(acetoxyethoxy)methyl (AcE), ${ }^{13} 2^{\prime}-O$-bis (methoxyethoxy)methyl (MeE), and 4/6- $N$-(4,4'-dimethoxytrityl) (DMTr) as protecting groups and imidazolium salt as the promoter. ${ }^{1}$ Here we report the synthesis of a complete collection of isotopically labeled and remotely tagged P-site substrates. Improved methods for synthesis of ${ }^{18} \mathrm{O}$-adenosine with the highest reported isotope enrichment and a general method for incorporation of ${ }^{18} \mathrm{O}$ into amino acids are also described.

\section{Results and Discussion}

The synthesis of CCA-pcb was first reported by coupling the trinucleotide CCA with cyanomethyl pcb. ${ }^{14}$ Although this synthesis provided synthetic access to the molecule, there were multiple byproducts that were difficult to separate from the authentic compound resulting in low overall yield. Furthermore, this approach could not be readily adapted to the synthesis of the target molecule with $\left[2^{\prime}-{ }^{18} \mathrm{O}\right]$ or $\left[3^{\prime}-{ }^{18} \mathrm{O}\right]$ adenosine, or with the remote isotope tags. We recently reported an alternative synthetic scheme for this compound that produced high yields and few side products. ${ }^{1}$ We used bulky bis(trimethylsiloxy)cyclododecyloxylsilyl (DOD) at the O5' of cytidine 3'-O-phosphoramidite (C74 in tRNA) and AcE at the O2' of the second cytidine (C75 in tRNA). This ensured the coupling between the 3'-O-phosphoramidite of the first nucleoside and the 5'-OH in the second nucleoside with its free 3 '-OH site reserved for the coupling to aminoacyladenosine, which is the last coupling step. We used the methyl phosphoramidite, which can be cleaved under mild conditions, and DMTr and ortho ester (AcE, $\mathrm{MeE}$ ) to protect unwanted nucleophilic sites. MeE was selected to protect 2'-OH to exclude possible hydrolysis of AcE during the cleavage of Fmoc. Both DMTr and ortho ester were removed under weak acidic conditions to ensure the full retention of the 3'-ester linkage and chirality within the peptide chain mimic. After exploring several nucleotide coupling conditions, we found that the phenylimidazolium salt of the phosphoramidite provided high 
coupling yields. Using this synthetic approach, the isotopomers of the P-site substrate were synthesized by coupling two fragments of similar sizes: cytidinyl-(3'5')-cytidine phosphoramidite (or its N3 and N4 substituted isotopomer) and isotopomers of A-pcb with substitutions at each of the relevant positions.

\section{Synthesis of $\mathbf{C}\left(3^{\prime} 5^{\prime}\right) \mathrm{C}$ phosphoramidite and its isotopomer}

There are three general methods to prepare $\left[3-{ }^{15} \mathrm{~N}, 4-{ }^{15} \mathrm{NH}_{2}\right]$ cytidine. The compound was synthesized by $\mathrm{S}_{\mathrm{N}} \mathrm{Ar}$ displacement of 4-oxo uridine followed by a Dimroth rearrangement of cytidine. ${ }^{15}$ An alternative method by a Dimroth-like rearrangement of $N^{3}$-activated uridine followed by $\mathrm{S}_{\mathrm{N}} \mathrm{Ar}$ reaction was also reported. ${ }^{16}$ The compound can also be prepared by construction of the pyrimidine ring followed by glycosylation. We used the well studied second method, and $\left[3-{ }^{15} \mathrm{~N}, 4-{ }^{15} \mathrm{NH}_{2}\right]$ cytidine $(\mathbf{1 b})$ was prepared according to a reported procedure by a Dimroth-like rearrangement of $2^{\prime}, 3^{\prime}, 5^{\prime}-O$-acetyl- $N^{3}$-nitrouridine and $\mathrm{S}_{\mathrm{N}} \mathrm{Ar}$ reaction of the intermediate $2^{\prime}, 3^{\prime}, 5^{\prime}-O$ acetyl- $\left[{ }^{15} N^{3}\right]$-uridine with in situ produced $\left({ }^{15} \mathrm{~N}^{\prime} \mathrm{H}_{3}\right.$ as a nucleophile, respectively, followed by deacetylation. ${ }^{16}$ Cytidine (1a) and its isotopomer (1b) were then treated with 1,3-dichloro-1,1,3,3-tetraisopropyldisiloxane ( $\mathrm{TIPDSCl}_{2}$ ) in pyridine, respectively, to afford 3',5'-O-(tetraisopropyldisiloxane-1,3-diyl)cytidine (92\%) and its isotopomer (90\%). ${ }^{12}$ Compound $\mathbf{2 a}, \mathbf{b}$ were selectively tritylated at the $\mathrm{N} 4$ to produce $\mathbf{3 a}, \mathbf{b}$ $(91 \%, 88 \%)$, which was further protected at the 2'-position by reflux with a mixture of trisacetoxyethoxy orthoformate, 4-tert-butyldimethylsiloxy-3-penten-2-one, and PPTS in DCM. The syrup that resulted after chromatograph was treated with HF-TMEDA in $\mathrm{CH}_{3} \mathrm{CN}$ to provide compound $\mathbf{5 a}, \mathbf{b}(71 \%, 86 \%)$, which was further protected at the 5 '-position by DOD $(89 \%, 89 \%)$. The cytidylyl phosphoramidites $\mathbf{7 a}, \mathbf{b}$ were obtained by treatment of compound 6a, $\mathbf{b}$ with methyl tetraisopropylphosphorodiamidite (POMe) in the presence of tetrazole in DCM overnight (81\%, quant.).

Compound 7a, $\mathbf{b}$ were directly coupled to compound $\mathbf{5 a}, \mathbf{b}$ in the presence of $\mathrm{PhImOTf}^{17}$ and molecule sieves in $\mathrm{CH}_{3} \mathrm{CN} / \mathrm{DCM}$ (1:1), followed by oxidation with $t$-BuOOH in toluene. The reaction selectively produced $\mathbf{8 a}, \mathbf{b}$ in good yield ( $81 \%$ and quant.) after chromatograph. Due to the large size of DOD at the O5' of compound $7 \mathbf{a}, \mathbf{b}$, the relatively large 2'-O-AcE of compound $\mathbf{5 a}, \mathbf{b}$, and large leaving group of phenylimidazole, only the 3 '-5' coupling products were detected, which were fully deprotected to give cytidylyl-(3'-5')-cytidine. The diribonucleotide was transformed into its phosphoramidite $\mathbf{9 a}, \mathbf{b}$ as before $(73 \%$ and $51 \%)$ (Scheme 1). Synthesis of the dinucleotide with tetrazole and 5-(ethylthio)- $1 H$-tetrazole only gave moderate yields, which might be caused by the bulky protecting groups as reasoned above.

\section{Synthesis of $\left[3^{\prime} / 2^{\prime}-{ }^{18} 0\right]$ adenosine derivative}

Methods for synthesis of ${ }^{18} \mathrm{O}$ nucleosides are limited, and this is especially true for substitutions within the ribosyl sugar. ${ }^{18,19,20,21}$ Hogencamp et al synthesized $\left[3^{\prime} / 2^{\prime}-{ }^{18} \mathrm{O}\right]$ adenosine by condensation of adenine with ribosyl chlorides to produce an isotope enrichment of $27 \%-33 \%$. ${ }^{18}$ Reversible hydration $\left(\mathrm{HCl} / \mathrm{H}_{2}{ }^{18} \mathrm{O}\right)$ of a 3'-ketouridine derivative followed by reduction $\left(\mathrm{NaBH}_{4}\right)$ and separation from the xylo epimer (major) gave $\left[3^{\prime}-{ }^{18} \mathrm{O}\right]$ uridine in low yield. ${ }^{21}$ Alternatively, the configurations of the 2'-C or 3'-C were inverted, the resulting 2'-OH or 3'$\mathrm{OH}$ were transformed into good leaving groups, and these were replaced to incorporate ${ }^{18} \mathrm{O}$. Using this strategy, Jiang C. et al. reported the synthesis of $2^{2}-{ }^{18} \mathrm{O}$-adenosine; however they had difficulty during triflation for the synthesis of $\left[3^{\prime}-{ }^{18} \mathrm{O}\right]$ adenosine, which was finally prepared via an epoxide intermediate ${ }^{20}$ For pyrimidine nucleosides, the inversion can be realized by formation of 2,2'- or 2,3'-anhydronucleosides, ${ }^{19,21}$

We initially attempted to prepare the $\left[3^{\prime}-{ }^{18} \mathrm{O}\right]$ adenosine according to a reported procedure via an epoxide intermediate. ${ }^{20}$ The epoxide 17 was prepared as reported. Cesium $\left[{ }^{18} \mathrm{O}_{2}\right]$ propionate was prepared by acidic hydrolysis of propionitrile in $\mathrm{HCl}-\mathrm{H}_{2}{ }^{18} \mathrm{O}$ in a pressure tube, which 
gave $94 \%$ of ${ }^{18} \mathrm{O}$ enrichment. This was in contrast to less than $50 \%$ enrichment reported for hydrolysis of propionyl chloride. Ring opening of the epoxide by cesium ${ }^{18} \mathrm{O}_{2}$-propionate $\left(94 \%{ }^{18} \mathrm{O}\right)$ gave multiple spots on TLC, in contrast to the reported regioselective ring opening. After deprotection, ion exchange chromatography revealed a 1.6:1 mixture of two major products, due to the two possible attacking sites. We reasoned that the formed alkoxide in the ring opening reaction may cause the disruption of glycosidic bond and hydrolysis of the $5^{\prime}$ ester. To avoid these side reactions, we employed a Lewis acid to neutralize the resulting alkoxide. In the presence of phenylimidazolium triflate, TLC showed clean reaction with two products. A moderate Lewis acid induced regioselectivity (3.6:1) for the production of compound 18. This may result from the increased steric hindrance in the possible hydrogen bonding complex between imidazolium and N3. Deprotection of 5'-O and 3'-O gave compound 18, which was selectively crystallized in the reaction mixture (63\%). The final incorporation of ${ }^{18} \mathrm{O}$ at $3^{\prime}$ was $93 \%$. Silylation of compound $\mathbf{1 8}$ by $\mathrm{TIDPSCl}_{2}$ at $3^{\prime}$ and $5^{\prime}$ positions (73\%), followed by similar inversion of configuration of the 2'-OH gave compound $\mathbf{2 1 f}$ ( $42 \%$ for three steps) (Scheme 2).

Although we improved the epoxide method, we still expected that the steroselective inversion $\left(\mathrm{S}_{\mathrm{N}} 2-\mathrm{S}_{\mathrm{N}} 2\right)$ strategy should provide an economical synthesis of the target compound 16f. We reasoned that the inaccessible triflation might be due to the bulky spherical TBS, which could be substituted with more suitable protecting groups. DMTr is propeller shaped just like diphenylimidazole, which in a reported alkylation study inefficiently excluded N7 alkylation of purine. ${ }^{22}$ Selective protection of 5'-O by DMTr is straightforward and may leave the 3'-OH accessible to triflation. Based upon this observation, compound $\mathbf{1 0}$ was prepared according to a reported procedure. ${ }^{23}$ The $3^{\prime}-\mathrm{OH}$ was triflate substituted in good yield (84\%). Nucleophilic displacement by cesium propionate (70\%) and hydrolysis (77\%) gave the xylofuranosyl nucleoside. Reactivation of 3'-OH by triflation and nucleophilic substitution incorporated ${ }^{18} \mathrm{O}$ at 3 ' position to give compound $\mathbf{1 5}$ in good yield (82\%). Full deprotection by sequential treatments with $\mathrm{NaOH}$ in dioxane- $\mathrm{H}_{2} \mathrm{O}$ and $\mathrm{HCOOH}$ in $\mathrm{MeOH}$ at $50{ }^{\circ} \mathrm{C}$ gave compound $16 \mathrm{f}$ $\left(61 \%\right.$ with $93 \%{ }^{18} \mathrm{O}$ incorporated at $\left.3^{\prime}\right)$. Because ${ }^{18} \mathrm{O}$ was introduced at a later stage in a stereoselective way, this more economical $\mathrm{S}_{\mathrm{N}} 2-\mathrm{S}_{\mathrm{N}} 2$ method was used in subsequent syntheses (Scheme 2).

Compound $\left[2^{\prime}-{ }^{18} \mathrm{O}\right]$ adenosine $(\mathbf{1 6 e})$ was synthesized according to the reported procedure from arabinofuranosyladenine, ${ }^{20}$ with high enrichment of ${ }^{18} \mathrm{O}(>90 \%)$, using the highly ${ }^{18} \mathrm{O}$ enriched cesium propionate. Compound 21a, $\mathbf{e}$, and $\mathbf{f}$ were selectively tritylated at the N6 to produce 22a, e, and $\mathbf{f}(91 \%, 84 \%$, and $93 \%)$, which were further protected at the 2 '-position by reflux with a mixture of trismethoxyethoxy orthoformate, 4-tert-butyldimethylsiloxy-3penten-2-one, and PPTS in DCM. The syrups that resulted after chromatograph were treated with HF-TMEDA in $\mathrm{CH}_{3} \mathrm{CN}$ to provide compound 23a, e, f $(71 \%, 74 \%$, and $70 \%)$, which was further protected by DOD to give 24a, e, f (89\%, 57\%, and 55\%) (Scheme 3).

\section{Synthesis of isotopically substituted $\mathbf{N}$-Fmoc-L-Phenylaniline}

To synthesize isotopically substituted CCA-pcb, isotopically substituted $N$-Fmoc-L-

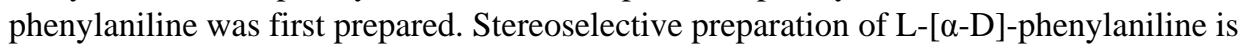
challenging, because of the sensitivity of its chirality to even weak bases. The reported syntheses include the introduction of deuterium by an enzymatic reductive amination, ${ }^{24}$ and full isotope exchange or chemical preparation of a mixture followed by enzymatic resolution of two enantiomers. 25,26

Because of the readily available deuterium source and acylase, we synthesized L-[ $\alpha-D]-$ phenylaniline by a reported method using enzymatic resolution. ${ }^{26} \mathrm{~N}$-Acetyl-DL-phenylalanine was treated with $\mathrm{NaOH}-\mathrm{D}_{2} \mathrm{O}$ at room temperature, and the resulting highly deuterium enriched (>98\% by NMR) $N$-acetyl-[ $\alpha$-D]-DL-phenylalanine was resolved by porcine kidney acylase 
at $\mathrm{pH} 7$ to give L-[ $\alpha-\mathrm{D}]-\mathrm{Phenyl}$ aniline in high purity, which was protected with Fmoc by treatment of Fmoc $O$-succinimide in $\mathrm{CH}_{3} \mathrm{CN}-\mathrm{H}_{2} \mathrm{O}$ (1:1) in the presence of $\mathrm{NaHCO}_{3}$ (quant.).

We were unable to identify a synthesis of $\mathrm{L}-\left[{ }^{18} \mathrm{O}_{2}\right]$-phenylaniline despite an extensive literature search. Sharpless and his coworkers reported a stereoselective synthesis of an L-

phenylgylcinonitrile derivative. ${ }^{27} \mathrm{We}$ thought acidic hydrolysis of a nitrile may not epimerize thechiral center. According to this procedure, we synthesized compound $\mathbf{2 7}$ by acetylating Lphenylglycinamide and treating the resulting $N$-actyl-L-phenylglycinamide with cyanuric chloride. ${ }^{28}$ The overall yield was $85 \%$ for two steps. $N$-Fmoc-L- $\left[{ }^{18} \mathrm{O}_{2}\right]$-phenylaniline was then synthesized byhydrolysis of compound 27 to give $\left[{ }^{18} \mathrm{O}_{2}\right]$-phenylaniline with high ${ }^{18} \mathrm{O}$ enrichment (quant, $>92 \%{ }^{18} \mathrm{O}$ ). Because of ${ }^{18} \mathrm{O} /{ }^{16} \mathrm{O}$ exchange between amino acids and $\mathrm{H}_{2} \mathrm{O}$ in aqueous solution, compound 28a was treated with Fmoc $N$-hydroxysuccinimide ester (Fmoc$\mathrm{OSu})(85 \%)$ in pyridine (Scheme 4).Significant epimerization was observed in spite of much lower $\mathrm{pK}_{\mathrm{a}}$ of pyridine than that of $\alpha-\mathrm{H}$ in phenylalanine.

\section{Synthesis of A-pcb and its isotopomers}

Aminoacylation of adenosine derivatives (24a, $\mathbf{e}$, and $\mathbf{f}$ ) was challenging because of the steric hindrance caused by the bulky 5'- and 2'- protecting groups (DOD and MeE) and the relative low nucleophilicity of the 3'-OH. Several coupling strategies such as acylation by acyl halides and DCC promoted esterification were attempted, but we achieved our best coupling using the imidazolium salt of the amino acid. Compounds 24a, e, and $\mathbf{f}$ were treated with $N$-Fmoc-Lphenylalanines in the presence of mesitylenesulfonyl tetrazole (MST) ${ }^{29}, 30$ and excess $N$ methylimidazole in DCM at ambient temperature to produce the fully protected derivative 30a, $\mathbf{d}, \mathbf{e}, \mathbf{f}, \mathbf{g}$, and $\mathbf{h}$ in reasonable to excellent yields (59\% - quant.). The reaction involves the imidazolium cation as shown by ${ }^{1} \mathrm{H}$ NMR. The imidazole was nucleophilically displaced as a neutral leaving group ${ }^{31}$ by the $3^{\prime}-\mathrm{OH}$ of $\mathbf{2 4 a}, \mathbf{e}$, and $\mathbf{f}$. All isotopomers are single distereomers as shown by ${ }^{1} \mathrm{H}$ NMR, except for $\mathbf{3 0 g}$. Compound $\mathbf{3 0 g}$ is a mixture of two distereomers as a result of the corresponding racemic $N$-Fmoc- ${ }^{18} \mathrm{O}_{2}$-phenylalanine. Removal of Fmoc by treatment of 30a, $\mathbf{d}, \mathbf{e ,} \mathbf{f}, \mathbf{g}$, and $\mathbf{h}$ with $20 \%$ piperidine in $\mathrm{CH}_{3} \mathrm{CN}$ resulted in $\mathbf{3 1 a}, \mathbf{d}, \mathbf{e ,} \mathbf{f}, \mathbf{g}$, and h. The two diostereomers of $\mathbf{3 1} \mathbf{g}$ were separated by careful column chromatography, and the correct component was used for later steps. DCC mediated amide formation with compound 32, followed by desilylation by treatment with HF-TMEDA in $\mathrm{CH}_{3} \mathrm{CN}$ gave 34a, d, e, $\mathbf{f}, \mathbf{g}$, and $\mathbf{h}$ in fair to good yields (Scheme 5). Compound $\mathbf{3 2}$ was prepared as reported ${ }^{1}$ with an improved high yield tritylation of methyl biotin in the presence of both $\mathrm{Et}_{3} \mathrm{~N}$ and DMAP in pyridine at $70{ }^{\circ} \mathrm{C}(88 \%)$.

\section{Synthesis of protected CCA-pcb isotopomers and their deprotection}

With compounds $\mathbf{9 a}, \mathbf{b}$ and $\mathbf{3 4 a}, \mathbf{d}-\mathbf{h}$ in hand, we performed the final steps of CCA-pcb isotopomer syntheses using our developed coupling method. ${ }^{1}$ Diribonucleotide phosphoramidite 9a, $\mathbf{b}$ were coupled to one molar equivalent of compound $\mathbf{3 4 a}, \mathbf{d}, \mathbf{e}, \mathbf{f}, \mathbf{g}$, and $\mathbf{h}$, using phenylimidazolium triflate (PhImOTf) and molecule sieves as the promotor in $\mathrm{CH}_{3} \mathrm{CN} / \mathrm{DCM}(1: 1)$ to form the fully protected CCA-pcb 35a-h in reasonable yields (33\% $72 \%$ ). The efficient 1:1 coupling reaction involves imidazolium cation, which was displaced by the 5'-OH to release a neutral leaving group. Desilylation of compound $\mathbf{3 5 a}-\mathbf{h}$ by treatment with HF-TMEDA in $\mathrm{CH}_{3} \mathrm{CN}$ and cleavage of methyl phosphate ester with $\mathrm{S}_{2} \mathrm{Na}_{2}, 13$ followed by complete removal of DMTr and orthoformate ester in $0.5 \mathrm{M} \mathrm{HCOOH}$ in MeOH-DCM (1:1) at $55^{\circ} \mathrm{C}$ for $5 \mathrm{~h}$ gave compound $\mathbf{1 a}(160 \mathrm{mg}, 59 \%), \mathbf{1 b}(40 \mathrm{mg}, 26 \%), \mathbf{1 c}(53 \mathrm{mg}, 28 \%), \mathbf{1 d}(21$ $\mathrm{mg}, 13 \%)$, and $\mathbf{1 h}(54 \mathrm{mg}, 62 \%)$ as essentially single isotopomers, and isotopically highly enriched 1e (86 mg, $30 \%$ with $93 \%$ of ${ }^{18} \mathrm{O}$ in $\left.\mathrm{A} 76\left(2^{\prime}-\mathrm{O}\right)\right)$, 1f $\left(16 \mathrm{mg}, 8 \%\right.$ with $93 \%$ of ${ }^{18} \mathrm{O}$ in A76 (3'-O)), and $1 \mathrm{~g}\left(12 \mathrm{mg}, 13 \%\right.$ with $64 \%$ of $\left.{ }^{18} \mathrm{O}(\mathrm{C}=\mathrm{O})\right)$ as a mixture of two regioisomers $\left(2^{\prime} / 3^{\prime}\right.$-ester as shown by ${ }^{1} \mathrm{H}$ NMR), respectively (Scheme 6$)$. The final relatively low enrichment 
(64\%) of ${ }^{18} \mathrm{O}$ in the carbonyl of compound $\mathbf{1 g}$ may be caused by ${ }^{18} \mathrm{O} /{ }^{16} \mathrm{O}$ exchange with adventitious $\mathrm{H}_{2} \mathrm{O}$ and with triflate in MST promoted aminoacylation.

\section{Summary and Conclusions}

In conclusion, we have accomplished the syntheses of a complete set of CCA-pcb isotopomers that will be used for a kinetic isotope effect analysis of the ribosomal peptidyl transfer reaction. These syntheses were made possible by improved methods for high yield synthesis of CCApcb. ${ }^{1}$ With its compatible coupling methods for nucleotide synthesis, amino acylation and mild deprotection conditions, 3', 5'-linkages were constructed exclusively, and the chirality of the amino acid and the labile $2 ' / 3^{\prime}$-ester linkage were conserved. The improved syntheses of $3^{\prime}-{ }^{18} \mathrm{O}$-adenosine with high heavy isotope enrichment have been developed, which provide an important small molecule probe for studies of nucleic acid related enzymes.

\section{Experimental Section}

2'-O-((Bisacetoxyethoxy)methyl)-5'-O-bis(trimethylsiloxy)cyclododecyloxysilyl-4- $\mathrm{N}-(4,4$ 'dimethoxytrityl)-[3-15 $\left.\mathrm{N}, 4-{ }^{15} \mathrm{NH}_{2}\right]$-cytidylyl-(3'5')-2'-O-((bisacetoxyethoxy)methyl)-4-N-(4,4'dimethoxytrityl)-[3- ${ }^{15} \mathrm{~N}, 4-{ }^{15} \mathrm{NH}_{2}$ ]-cytidine 3'-( $\mathrm{N}, \mathrm{N}$-diisopropylmethoxy)phosphoramidite (9b)

To compound $8 \mathbf{b}(3.2 \mathrm{~g}, 1.6 \mathrm{mmol})$ in a dry flask was added tetrazole in $\mathrm{CH}_{3} \mathrm{CN}(3 \mathrm{wt}$ \% $\%, 5.5$ $\mathrm{mL}, 1.9 \mathrm{mmol})$, and volatiles were evaporated under vacuum to give a solid residue. DCM (10 $\mathrm{mL})$ and methyl tetraisopropylphosphorodiamidite $(1.3 \mathrm{~mL}, 1.2 \mathrm{~g}, 1.8 \mathrm{mmol})$ were added, and the resulting solution was stirred under Ar at room temperature for $11 \mathrm{~h}$. TLC (EtOAc/hexanes, 85:15) showed complete reaction. The reaction mixture was then diluted by addition of DCM $(50 \mathrm{~mL})$, and the resulting solution was washed with $\mathrm{NaCl} / \mathrm{H}_{2} \mathrm{O}(30 \times 2 \mathrm{~mL})$. The organic layer was separated and dried $\left(\mathrm{MgSO}_{4}\right)$, and volatiles were evaporated under vacuum. The derived residue was chromatographed (DCM/hexanes, $3: 7 \rightarrow 2: 3$ with $10 \% \mathrm{Et}_{3} \mathrm{~N}$ ) to give compound 9b $(1.3 \mathrm{~g}, 51 \%)$ (four distereomers) with ${ }^{1} \mathrm{H}$ and ${ }^{31} \mathrm{P}$ NMR spectra identical to those of compound 9a; ESI-MS $\left(\mathrm{ES}^{+}\right) \mathrm{m} / \mathrm{z} 2156.88\left([\mathrm{M}+\mathrm{H}]^{+}\left[\mathrm{C}_{104} \mathrm{H}_{147} \mathrm{~N}_{3}{ }^{15} \mathrm{~N}_{4} \mathrm{O}_{32} \mathrm{P}_{2} \mathrm{Si}_{3}\right]=2156.88\right)$.

\section{6-N-Benzoyl-2'-O-t-butyldimethylsilyl-5'-O-(4,4'-dimethoxytrityl)-3'- Otrifluoromethanesulfonyladenosine (11)}

2'-O-t-Butyldimethylsilyl-5'-O-(4,4'-dimethoxytrityl)-6- $\mathrm{N}$-benzoyladenosine ( $0.98 \mathrm{~g}, 1.2$ mmol) and DMAP (230 mg, $1.9 \mathrm{mmol})$ was dried by coevaporation with DCM $(10 \mathrm{~mL})$. The mixture was then dissolved in DCM $(15 \mathrm{~mL})$, and cooled in ice-water bath under Ar. To this solution was added trifluoromethanesulfonyl chloride $(0.32 \mathrm{~g}, 1.9 \mathrm{mmol})$, and the reaction mixture was stirred at $0{ }^{\circ} \mathrm{C}$ under $\mathrm{Ar}$ for about $1 \mathrm{~h}$ (TLC showed complete reaction). The reaction mixture was poured into ice-cold saturated $\mathrm{NaHCO}_{3}-\mathrm{H}_{2} \mathrm{O}(50 \mathrm{~mL})$, and extracted with $\mathrm{DCM}(50 \times 2 \mathrm{~mL})$. The organic layer was separated, washed twice with saturated $\mathrm{NaHCO}_{3}-$ $\mathrm{H}_{2} \mathrm{O}(50 \times 2 \mathrm{~mL})$, and dried $\left(\mathrm{MgSO}_{4}\right)$. Volatiles were evaporated under vacuum, and the resulting mixture was chromatographed (EtOAc/hexanes, 3:7) to give compound $\mathbf{1 1}(0.96 \mathrm{~g}$, 84\%): ${ }^{1} \mathrm{H}$ NMR $\left(500 \mathrm{MHz}\right.$, DMSO- $\left.d_{6}\right) \delta 11.36(\mathrm{~s}, 1 \mathrm{H}), 8.81(\mathrm{~s}, 1 \mathrm{H}), 8.67(\mathrm{~s}, 1 \mathrm{H}), 8.12(\mathrm{~d}, J=$ $7.3 \mathrm{~Hz}, 2 \mathrm{H}), 7.74-6.94(\mathrm{~m}, 16 \mathrm{H}), 6.22(\mathrm{~d}, J=7.5 \mathrm{~Hz}, 1 \mathrm{H}), 5.64-5.66(\mathrm{~m}, 1 \mathrm{H}), 5.57-5.58(\mathrm{~m}$, $1 \mathrm{H}), 4.61(\mathrm{t}, J=5.4 \mathrm{~Hz}, 1 \mathrm{H}), 3.82(\mathrm{~s}, 6 \mathrm{H}), 3.65(\mathrm{dd}, J=5.5,8.3 \mathrm{~Hz}, 1 \mathrm{H}), 3.50(\mathrm{dd}, J=5.5,8.3$ $\mathrm{Hz}, 1 \mathrm{H}), 0.77$ (s, 9H), 0.00 (s, 3H), -0.41 (s, 3H).

\section{6-N-Benzoyl-[2'-O-t-butyldimethylsilyl-5'-O-(4,4'-dimethoxytrityl)-3'-O-propionyl-1- xylofuranosyl]adenine (12)}

A mixture of compound $11(0.96 \mathrm{~g}, 1 \mathrm{mmol})$ and cesium propionate $(0.46 \mathrm{~g}, 2.1 \mathrm{mmol})$ was dissolved in anhydrous DMF $(10 \mathrm{~mL})$, and the solution was stirred under Ar at room temperature overnight. Volatiles were evaporated under vacuum, and the residue was chromatographed (EtOAc/hexanes, 3:7) to give compound 12 (0.61 g, 70\%): ${ }^{1} \mathrm{H}$ NMR (500 
MHz, DMSO- $\left.d^{6}\right) \delta 11.17(\mathrm{~s}, 1 \mathrm{H}), 8.67(\mathrm{~s}, 1 \mathrm{H}), 8.34(\mathrm{~s}, 1 \mathrm{H}), 8.00(\mathrm{~d}, J=7.4 \mathrm{~Hz}, 2 \mathrm{H}), 7.06-6.81$ $(\mathrm{m}, 16 \mathrm{H}), 6.07(\mathrm{~d}, J=3.4 \mathrm{~Hz}, 1 \mathrm{H}), 5.21-5.19(\mathrm{~m}, 1 \mathrm{H}), 4.97-4.96(\mathrm{~m}, 1 \mathrm{H}), 4.57-4.54(\mathrm{~m}, 1 \mathrm{H})$, $3.69(\mathrm{~s}, 6 \mathrm{H}), 3.36(\mathrm{dd}, J=6.5,8.4 \mathrm{~Hz}, 1 \mathrm{H}), 3.15(\mathrm{dd}, J=4.7,7.5 \mathrm{~Hz}, 1 \mathrm{H}), 2.03-1.92(\mathrm{~m}, 2 \mathrm{H})$, $0.78(\mathrm{~s}, 9 \mathrm{H}), 0.75(\mathrm{t}, J=7.5 \mathrm{~Hz}, 3 \mathrm{H}), 0.00(\mathrm{~s}, 3 \mathrm{H}),-0.10(\mathrm{~s}, 3 \mathrm{H})$.

\section{(2'-O-t-Butyldimethylsilyl-5'-O-(4,4'-dimethoxytrityl)-9-xylofuranosyl)adenine (13)}

To a solution of compound $12(0.61 \mathrm{~g}, 0.72 \mathrm{mmol})$ in $\mathrm{MeOH}(20 \mathrm{~mL})$ was added $\mathrm{K}_{2} \mathrm{CO}_{3}(0.5$ $\mathrm{g}, 3.6 \mathrm{mmol}$ ), and the mixture was stirred at room temperature overnight (TLC showed complete reaction). Volatiles were evaporated under vacuum, and the residue was chromatographed (EtOAc/hexanes, $1: 1 \rightarrow 7: 3 \rightarrow$ EtOAc) to give compound $\mathbf{1 3}(0.38 \mathrm{~g}$, 77\%): ${ }^{1} \mathrm{H}$ NMR (500 MHz, DMSO- $\left.d_{6}\right) \delta 8.07(\mathrm{~s}, 1 \mathrm{H}), 8.01(\mathrm{~s}, 1 \mathrm{H}), 7.37-6.85(\mathrm{~m}, 15 \mathrm{H}), 5.86$ (br s, $1 \mathrm{H}), 5.68(\mathrm{~d}, J=4.8 \mathrm{~Hz}, 1 \mathrm{H}), 4.38(\mathrm{br} \mathrm{s}, 1 \mathrm{H}), 4.28-4.25(\mathrm{~m}, 1 \mathrm{H}), 3.92-3.90(\mathrm{~m}, 1 \mathrm{H}), 3.68$ (s, 6H), 3.45 (dd, $J=9.9,10.2 \mathrm{~Hz}, 1 \mathrm{H}), 3.50(\mathrm{dd}, J=1.4,5.2 \mathrm{~Hz}, 1 \mathrm{H}), 0.80(\mathrm{~s}, 9 \mathrm{H}), 0.00$ (s, $6 \mathrm{H})$.

\section{[2'-O-t-Butyldimethylsilyl-5'-O-(4,4'-dimethoxytrityl)-3'-O-trifluoromethanesulfonyl-9- xylofuranosyl]adenine (14)}

Compound $13(0.38 \mathrm{~g}, 0.6 \mathrm{mmol})$ and DMAP $(115 \mathrm{mg}, 0.9 \mathrm{mmol})$ was dried by coevaporation with DCM $(10 \mathrm{~mL})$. The mixture was then dissolved in DCM $(15 \mathrm{~mL})$, and cooled in ice-water bath under Ar. To this solution was added trifluoromethanesulfonyl chloride $(0.16 \mathrm{~g}, 0.98$ $\mathrm{mmol}$ ), and the reaction mixture was stirred at $0{ }^{\circ} \mathrm{C}$ under Ar for about $1 \mathrm{~h}$ (TLC showed complete reaction). The reaction mixture was poured into ice-cold saturated $\mathrm{NaHCO}_{3}-\mathrm{H}_{2} \mathrm{O}$ $(50 \mathrm{~mL})$, and extracted with DCM $(50 \times 2 \mathrm{~mL})$. The organic layer was separated, washed twice with saturated $\mathrm{NaHCO}_{3}-\mathrm{H}_{2} \mathrm{O}(50 \times 2 \mathrm{~mL})$, and dried $\left(\mathrm{MgSO}_{4}\right)$. Volatiles were evaporated under vacuum, and the resulting mixture was chromatographed (MeOH/DCM, 1:30) to give the compound (0.46 g, quant.): ${ }^{1} \mathrm{H}$ NMR $\left(500 \mathrm{MHz}\right.$, DMSO- $\left.d_{6}\right) \delta 8.19(\mathrm{~s}, 1 \mathrm{H}), 8.12(\mathrm{~s}, 1 \mathrm{H}), 7.42-$ $6.83(\mathrm{~m}, 13 \mathrm{H}), 6.03(\mathrm{~d}, J=4.8 \mathrm{~Hz}, 1 \mathrm{H}), 5.71-5.69(\mathrm{~m}, 1 \mathrm{H}), 5.42-5.40(\mathrm{~m}, 1 \mathrm{H}), 4.67-4.64(\mathrm{~m}$, $1 \mathrm{H}), 3.72(\mathrm{~s}, 6 \mathrm{H}), 3.49-3.48(\mathrm{~m}, 1 \mathrm{H}), 3.25-3.20(\mathrm{~m}, 1 \mathrm{H}), 0.77(\mathrm{~s}, 9 \mathrm{H}), 0.00(\mathrm{~s}, 3 \mathrm{H}),-0.29(\mathrm{~s}$, $3 \mathrm{H})$.

\section{2'-O-t-Butyldimethylsilyl-5'-O-(4,4'-dimethoxytrityl)-[3'-180]-3'-O-(-propionyl)adenosine (15)}

${ }^{18} \mathrm{O}_{2}$-Propionate cesium was prepared by acidic hydrolysis of propionitrile in $\mathrm{HCl}-\mathrm{H}_{2}{ }^{18} \mathrm{O}$. $\mathrm{H}_{2}{ }^{18} \mathrm{O}(10 \mathrm{~g})$ was saturated with $\mathrm{HCl}$ at $0{ }^{\circ} \mathrm{C}$, and to this cold solution added propionitrile ( 3 $\mathrm{mL}, 2.32 \mathrm{~g}, 42 \mathrm{mmol})$. The solution was stirred in a pressure tube at $120^{\circ} \mathrm{C} 21$ for $48 \mathrm{~h}$. The yellow solution was cooled in ice-water bath, and solid precipitated out. The acidic $\mathrm{H}_{2}{ }^{18} \mathrm{O}$ was collected for recycling, and the solid was dissolved in DCM $(50 \mathrm{~mL})$. The solution was extracted with ice-cold $\mathrm{NaHCO}_{3}-\mathrm{H}_{2} \mathrm{O}$, and the aqueous solution was washed with DCM. The aqueous solution was acidified by addition of $\mathrm{HCl}-\mathrm{H}_{2} \mathrm{O}$ till about $\mathrm{pH} 3$, and extracted with DCM. The organic layer was separated, and dried $\left(\mathrm{MgSO}_{4}\right)$. Vacuum fractional distillation gave ${ }^{18} \mathrm{O}_{2}$-propionoic acid as a clear colorless liquid.

The liquid was added to $\mathrm{MeOH}(40 \mathrm{~mL})$ in a flask, and to this solution was added $\mathrm{Cs}_{2} \mathrm{CO}_{3}(1.0$ $\mathrm{g}, 3.1 \mathrm{mmol})$. The mixture was stirred at room temperature for $3 \mathrm{~h}$, and volatiles were evaporated under vacuum to give a solid residue, which was thoroughly washed with $\mathrm{Et}_{2} \mathrm{O}$ to give the cesium salt $(1.4 \mathrm{~g}, 95 \%)$ : ESI-MS $\left(\mathrm{ES}^{-}\right) \mathrm{m} / \mathrm{z} 75\left([\mathrm{M}-\mathrm{H}]^{-}\left[\mathrm{C}_{3} \mathrm{H}_{5}{ }^{18} \mathrm{OO}\right]=75,12 \%\right)$, $77\left([\mathrm{M}-\mathrm{H}]^{-}\left[\mathrm{C}_{3} \mathrm{H}_{5}{ }^{18} \mathrm{O}_{2}\right]=77,88 \%\right)$.

Compound $14(0.46 \mathrm{~g}, 0.56 \mathrm{mmol})$ and cesium $\left[{ }^{18} \mathrm{O}_{2}\right]$ propionate $(0.23 \mathrm{~g}, 1.1 \mathrm{mmol})$ was dissolved in anhydrous DMF $(10 \mathrm{~mL})$, and the resulting solution was stirred at room temperature under Ar overnight. Volatiles were removed under vacuum at $37{ }^{\circ} \mathrm{C}$, and the solid residue was chromatographed (EtOAc/hexanes, $1: 1 \rightarrow 7: 3)$ to give compound $\mathbf{1 5}(0.34 \mathrm{~g}$, 81\%): ${ }^{1} \mathrm{H}$ NMR (500 MHz, DMSO- $\left.d_{6}\right) \delta 8.44(\mathrm{~s}, 1 \mathrm{H}), 8.16(\mathrm{~s}, 1 \mathrm{H}), 7.55-6.97(\mathrm{~m}, 13 \mathrm{H}), 6.03$ 
$(\mathrm{d}, J=7.1 \mathrm{~Hz}, 1 \mathrm{H}), 5.51-5.51(\mathrm{~m}, 1 \mathrm{H}), 5.40-5.39(\mathrm{~m}, 1 \mathrm{H}), 4.36(\mathrm{br} \mathrm{s}, 1 \mathrm{H}), 3.86(\mathrm{~s}, 6 \mathrm{H}), 3.48-3.44$ (m, 2H), 2.58-2.49 (m, 2H), $1.19(\mathrm{t}, J=7.6 \mathrm{~Hz}, 3 \mathrm{H}), 0.78(\mathrm{~s}, 9 \mathrm{H}), 0.00(\mathrm{~s}, 3 \mathrm{H}),-0.23(\mathrm{~s}, 3 \mathrm{H})$.

\section{[3'-180] Adenosine (16f)}

To a solution of compound $15(0.34 \mathrm{~g}, 0.46 \mathrm{mmol})$ in dioxane $(5 \mathrm{~mL})$ was added $1 \mathrm{M} \mathrm{NaOH}-$ $\mathrm{H}_{2} \mathrm{O}(5 \mathrm{~mL})$, and the turbid solution was stirred at room temperature overnight. The solution was neutralized by bubbling through $\mathrm{CO}_{2}$. Volatiles were evaporated under vacuum, and the residue was chromatographed (MeOH/DCM. 1:15) to give a white solid.

This white solid was then dissolved in $\mathrm{MeOH} / \mathrm{DCM}(1: 1,10 \mathrm{~mL})$, and to the clear solution was added $88 \%$ formic acid $(0.22 \mathrm{~mL}, 0.26 \mathrm{~g}, 5 \mathrm{mmol})$. The solution was stirred at $50{ }^{\circ} \mathrm{C}$ for $11 \mathrm{~h}$ (TLC showed complete reaction). The volatiles were evaporated under vacuum, and the residue was thoroughly washed (DCM) to give a white solid (77 mg, 63\%) with ${ }^{1} \mathrm{H}$ and ${ }^{13} \mathrm{C}$ NMR spectra identical to the authentic sample; ESI-MS $\left(\mathrm{ES}^{+}\right) \mathrm{m} / \mathrm{z} 268([\mathrm{M}+$ $\left.\mathrm{H}]^{+}\left[\mathrm{C}_{10} \mathrm{H}_{13} \mathrm{~N}_{5} \mathrm{O}_{4}\right]=268,8.4 \%\right), 270\left([\mathrm{M}+\mathrm{H}]^{+}\left[\mathrm{C}_{10} \mathrm{H}_{13} \mathrm{~N}_{5} \mathrm{O}_{3}{ }^{18} \mathrm{O}\right]=270,91.6 \%\right)$.

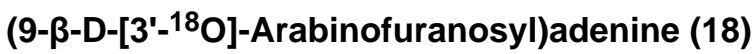

A mixture of compound $\mathbf{1 7}(0.86 \mathrm{~g}, 3.0 \mathrm{mmol})$, phenylimidazolium triflate $(0.97 \mathrm{~g}, 3.3 \mathrm{mmol})$ and ${ }^{18} \mathrm{O}_{2}$-propionate cesium $(0.93 \mathrm{~g}, 4.4 \mathrm{mmol})$ in DMF was stirred at $120{ }^{\circ} \mathrm{C}$ and at the presence of dried molecular sieves for $6 \mathrm{~h}$. Volatiles were evaporated under vacuum. The derived residue was dissolved in $\mathrm{MeOH}(40 \mathrm{~mL})$ in a sealed flask, and to this solution was added $\mathrm{NH}_{3} \cdot \mathrm{H}_{2} \mathrm{O}(4 \mathrm{~mL})$. The mixture was stirred at ambient temperature overnight. The precipitated solid was collected by filtration to give compound $18(0.5 \mathrm{~g}, 63 \%)$ with with ${ }^{1} \mathrm{H}$ and ${ }^{13} \mathrm{C}$ NMR spectra identical to the authentic unlabeled sample; ESI-MS $\left(\mathrm{ES}^{+}\right) \mathrm{m} / \mathrm{z} 268$ ([M $\left.+\mathrm{H}]^{+}\left[\mathrm{C}_{10} \mathrm{H}_{13} \mathrm{~N}_{5} \mathrm{O}_{4}\right]=268,7.4 \%\right), 270\left([\mathrm{M}+\mathrm{H}]^{+}\left[\mathrm{C}_{10} \mathrm{H}_{13} \mathrm{~N}_{5} \mathrm{O}_{3}{ }^{18} \mathrm{O}\right]=270,92.6 \%\right)$. The mother liquor was dried by evaporation in vacuo, and the solid residue was washed thoroughly with $\mathrm{MeOH}$ to give a crude mixture of the needed product and (9- $\left.\beta-\mathrm{D}-2^{\prime}-{ }^{18} \mathrm{O}-\mathrm{xylofuranosyl}\right)$ adenine, which was treated with TIPDSCl$_{2}$ to give silylated byproduct $(0.20 \mathrm{~g})$.

\section{$\mathrm{L}-\left[{ }^{18} \mathrm{O}_{2}\right]-$ Phenyl aniline (28a)}

$\mathrm{H}_{2}{ }^{18} \mathrm{O}(10 \mathrm{~g})$ was saturated with $\mathrm{HCl}$ at $0^{\circ} \mathrm{C}$, and to this cold solution added compound 27 $(1.5 \mathrm{~g}, 7.8 \mathrm{mmol})$. The suspension was stirred at $120^{\circ} \mathrm{C}$ to give a clear brown solution after $10 \mathrm{~min}$, and the solution was further stirred for $48 \mathrm{~h}$. The yellow solution was cooled in icewater bath, and solid precipitated out. The acidic $\mathrm{H}_{2}{ }^{18} \mathrm{O}$ was collected for future use, and the solid was dissolved in $\mathrm{MeOH}(50 \mathrm{~mL})$. Volatiles were evaporated in vacuo, and the residue was thoroughly washed with DCM to give crude compound 28a (including $\mathrm{NH}_{4} \mathrm{Cl}$ ): ESI-MS $\left(\mathrm{ES}^{+}\right) \mathrm{m} / \mathrm{z} 168\left(\mathrm{M}+\mathrm{H}^{+}\left[\mathrm{C}_{9} \mathrm{H}_{12}{ }^{18} \mathrm{OO}\right]=168,9.5 \%\right), 170\left(\mathrm{M}+\mathrm{H}^{+}\left[\mathrm{C}_{9} \mathrm{H}_{12}{ }^{18} \mathrm{O}_{2}\right]=170,90.5 \%\right)$.

\section{Cytidylyl-(3'5')-cytidylyl-(3'5')-3'(2')-O-(N-(6-D-(+)-biotinoylaminohexanoyl)-L-phenylalanyl) adenosine isotopomers (CCA-pcb, 1a-h)}

A freshly prepared HF-TMEDA solution in DMF $(0.4 \mathrm{M}, 12.5$ eq.) was added to a flask containing compound 35a/b/c/d/e/f/g/h $(0.95 \mathrm{~g}, 0.27 \mathrm{mmol} / 0.21 \mathrm{~g}, 0.06 \mathrm{mmol} / 0.50 \mathrm{~g}, 0.14$ $\mathrm{mmol} / 0.41 \mathrm{~g}, 0.12 \mathrm{mmol} / 0.77 \mathrm{~g}, 0.21 \mathrm{mmol} / 0.53 \mathrm{~g}, 0.15 \mathrm{mmol} / 0.23 \mathrm{~g}, 0.06 \mathrm{mmol} / 0.28 \mathrm{~g}, 0.08$ $\mathrm{mmol}$ ), respectively, and the resulting solution was stirred for $0.5 \mathrm{~h}$. TLC showed complete reaction. Volatiles were evaporated under vacuum and coevaporated with toluene, and the residue was separated by preparative TLC $(\mathrm{MeOH} / \mathrm{DCM}, 1: 15 \rightarrow 1: 10)$ to give a solid.

$\mathrm{S}_{2} \mathrm{Na}_{2} \cdot 3 \mathrm{H}_{2} \mathrm{O}$ was dissolved in $\mathrm{H}_{2} \mathrm{O} / \mathrm{DMF}\left(0.1 \mathrm{M}, 2 \% \mathrm{H}_{2} \mathrm{O}\right)$. To the clear lightly yellow solution was added the solid, and the resulting clear solution was stirred at room temperature for $1 \mathrm{~h}$. TLC showed complete reaction. $\mathrm{S}_{2} \mathrm{Na}_{2}$ was then partially precipitated by addition of DCM ( 25 $\mathrm{mL})$ and removed by centrifuge. The solid was extracted with DCM $(5 \mathrm{~mL})$, and the clear 
solutions were combined. Volatiles were evaporated under vacuum, and the residue was suspended in limited amount of MeOH/DCM (1:3). The resulting solution was separated by preparative TLC (MeOH/DCM, 1:6 $\rightarrow 1: 3.6)$ to give a solid.

To the obtained solid in a dry flask was added freshly prepared $0.5 \mathrm{M} \mathrm{HCOOH}$ in DCM/ $\mathrm{CH}_{3} \mathrm{OH}(1: 1)$. The clear solution was stirred at $55^{\circ} \mathrm{C}$ for $5 \mathrm{~h}$ with precipitated product observed. Volatiles were evaporated, and coevaporated with toluene twice. The residue was dried under vacuum overnight, and then washed with $\mathrm{MeOH} / \mathrm{DCM}(1: 2)$ at $37^{\circ} \mathrm{C}$ to give compound 1a$\mathbf{h}$ (two regioisomers).

Compound 1a (160 mg, 59\%): ESI-MS (ES $\left.{ }^{-}\right) \mathrm{m} / z 1362.51\left([\mathrm{M}-\mathrm{H}]{ }^{-}\left[\mathrm{C}_{53} \mathrm{H}_{70} \mathrm{~N}_{15} \mathrm{O}_{22} \mathrm{P}_{2} \mathrm{~S}\right]\right.$ $=1362.40), 1384.54\left([\mathrm{M}-2 \mathrm{H}+\mathrm{Na}]^{-}\left[\mathrm{C}_{53} \mathrm{H}_{69} \mathrm{~N}_{15} \mathrm{O}_{22} \mathrm{P}_{2} \mathrm{~S} \mathrm{Na}\right]=1384.40\right)$.

Compound 1b (40 mg, 26\%): ESI-MS (ES $\left.{ }^{-}\right) \mathrm{m} / z 682.90\left([\mathrm{M}-2 \mathrm{H}]^{2-}\right.$ $\left.\left[\mathrm{C}_{53} \mathrm{H}_{69}{ }^{15} \mathrm{~N}_{4} \mathrm{~N}_{11} \mathrm{O}_{22} \mathrm{P}_{2} \mathrm{~S}\right]=682.70\right), 1366.81\left([\mathrm{M}-\mathrm{H}]^{-}\left[\mathrm{C}_{53} \mathrm{H}_{70}{ }^{15} \mathrm{~N}_{4} \mathrm{~N}_{11} \mathrm{O}_{22} \mathrm{P}_{2} \mathrm{~S}\right]=1366.40\right)$, $1388.77\left([\mathrm{M}-2 \mathrm{H}+\mathrm{Na}]^{-}\left[\mathrm{C}_{53} \mathrm{H}_{69}{ }^{15} \mathrm{~N}_{4} \mathrm{~N}_{11} \mathrm{O}_{22} \mathrm{P}_{2} \mathrm{~S} \mathrm{Na}\right]=1386.40\right)$.

Compound 1c (53 mg, 28\%): ESI-MS (ES $\left.{ }^{-}\right) \mathrm{m} / 2683.49\left([\mathrm{M}-2 \mathrm{H}]^{2-}\right.$ $\left.\left[\mathrm{C}_{52}{ }^{13} \mathrm{CH}_{69}{ }^{15} \mathrm{~N}_{4} \mathrm{~N}_{11} \mathrm{O}_{22} \mathrm{P}_{2} \mathrm{~S}\right]=683.20\right), 1367.95\left([\mathrm{M}-\mathrm{H}]^{-}\left[\mathrm{C}_{52}{ }^{13} \mathrm{CH}_{70}{ }^{15} \mathrm{~N}_{4} \mathrm{~N}_{11} \mathrm{O}_{22} \mathrm{P}_{2} \mathrm{~S}\right]=\right.$ 1367.40), $1389.91\left([\mathrm{M}-2 \mathrm{H}+\mathrm{Na}]^{-}\left[\mathrm{C}_{52}{ }^{13} \mathrm{CH}_{69}{ }^{15} \mathrm{~N}_{4} \mathrm{~N}_{11} \mathrm{O}_{22} \mathrm{P}_{2} \mathrm{~S} \mathrm{Na}\right]=1389.40\right)$ with an extremely abundant peak at $170.7 \mathrm{ppm}$ in ${ }^{13} \mathrm{C}$ NMR.

Compound 1d (21 mg, 13\%): ESI-MS (ES $\left.{ }^{-}\right) \mathrm{m} / z 683.41\left([\mathrm{M}-2 \mathrm{H}]^{2-}\right.$ $\left.\left[\mathrm{C}_{53}{ }^{2} \mathrm{HH}_{68}{ }^{15} \mathrm{~N}_{4} \mathrm{~N}_{11} \mathrm{O}_{22} \mathrm{P}_{2} \mathrm{~S}\right]=683.20\right), 1367.82\left([\mathrm{M}-\mathrm{H}]{ }^{-}\left[\mathrm{C}_{53}{ }^{2} \mathrm{HH}_{69}{ }^{15} \mathrm{~N}_{4} \mathrm{~N}_{11} \mathrm{O}_{22} \mathrm{P}_{2} \mathrm{~S}\right]=\right.$ 1367.40).

Compound 1e (86 mg, 30\%): ESI-MS (ES $\left.{ }^{-}\right) \mathrm{m} / \mathrm{z} 681.65\left([\mathrm{M}-2 \mathrm{H}]^{2-}\right.$

$\left.\left[\mathrm{C}_{53} \mathrm{H}_{69} \mathrm{~N}_{15} \mathrm{O}_{21}{ }^{18} \mathrm{OP}_{2} \mathrm{~S}\right]=681.70\right), 1364.40\left([\mathrm{M}-\mathrm{H}]^{-}\left[\mathrm{C}_{53} \mathrm{H}_{70} \mathrm{~N}_{15} \mathrm{O}_{21}{ }^{18} \mathrm{O} \mathrm{P}_{2} \mathrm{~S}\right]=1364.40\right)$, $1375.90\left([2 \mathrm{M}+\mathrm{Na}-2 \mathrm{H}]^{2-}\left[\mathrm{C}_{106} \mathrm{H}_{140} \mathrm{~N}_{30} \mathrm{O}_{42}{ }^{18} \mathrm{O}_{2} \mathrm{P}_{4} \mathrm{~S}_{2} \mathrm{Na}\right]=1375.90\right), 1386.37([\mathrm{M}-2 \mathrm{H}+$ $\left.\mathrm{Na}]^{-}\left[\mathrm{C}_{53} \mathrm{H}_{69} \mathrm{~N}_{15} \mathrm{O}_{21}{ }^{18} \mathrm{O} \mathrm{P}_{2} \mathrm{SNa}\right]=1386.40\right)$.

Compound 1f (16 mg, 8\%): ESI-MS $\left(\mathrm{ES}^{-}\right) \mathrm{m} / \mathrm{z} 681.69\left([\mathrm{M}-2 \mathrm{H}]^{2-}\left[\mathrm{C}_{53} \mathrm{H}_{69} \mathrm{~N}_{15} \mathrm{O}_{21}{ }^{18} \mathrm{OP}_{2} \mathrm{~S}\right]\right.$ $=681.70), 1364.42\left([\mathrm{M}-\mathrm{H}]^{-}\left[\mathrm{C}_{53} \mathrm{H}_{70} \mathrm{~N}_{15} \mathrm{O}_{21}{ }^{18} \mathrm{O} \mathrm{P} \mathrm{P}_{2} \mathrm{~S}\right]=1364.40\right), 1386.39([\mathrm{M}-2 \mathrm{H}+$ $\left.\mathrm{Na}]^{-}\left[\mathrm{C}_{53} \mathrm{H}_{69} \mathrm{~N}_{15} \mathrm{O}_{21}{ }^{18} \mathrm{O} \mathrm{P}_{2} \mathrm{SNa}\right]=1386.40\right)$.

Compound 1g (12 mg, 13\%): ESI-MS (ES $\left.{ }^{-}\right) \mathrm{m} / z 680.72\left([\mathrm{M}-2 \mathrm{H}]^{2-}\left[\mathrm{C}_{53} \mathrm{H}_{69} \mathrm{~N}_{15} \mathrm{O}_{22} \mathrm{P} 2 \mathrm{~S}\right]=\right.$ 680.70, 35.7\%), $681.72\left([\mathrm{M}-2 \mathrm{H}]^{2-}\left[\mathrm{C}_{53} \mathrm{H}_{69} \mathrm{~N}_{15} \mathrm{O}_{21}{ }^{18} \mathrm{OP}_{2} \mathrm{~S}\right]=681.70,64.3 \%\right), 1362.38([\mathrm{M}$ $\left.-\mathrm{H}]^{-}\left[\mathrm{C}_{53} \mathrm{H}_{70} \mathrm{~N}_{15} \mathrm{O}_{22} \mathrm{P}_{2} \mathrm{~S}\right]=1362.40,33.5 \%\right), 1364.38\left([\mathrm{M}-\mathrm{H}]^{-}\left[\mathrm{C}_{53} \mathrm{H}_{70} \mathrm{~N}_{15} \mathrm{O}_{21}{ }^{18} \mathrm{O} \mathrm{P}_{2} \mathrm{~S}\right]\right.$ $=1364.40,66.5 \%)$.

Compound 1h (54 mg, 62\%): ESI-MS (ES $\left.{ }^{-}\right) \mathrm{m} / \mathrm{z} 681.45\left([\mathrm{M}-2 \mathrm{H}]^{2-}\left[\mathrm{C}_{52}{ }^{13} \mathrm{C}\right.\right.$ $\left.\left.\mathrm{H}_{69} \mathrm{~N}_{15} \mathrm{O}_{22} \mathrm{P}_{2} \mathrm{~S}\right]=681.20\right), 1363.74\left([\mathrm{M}-\mathrm{H}]^{-}\left[\mathrm{C}_{52}{ }^{13} \mathrm{CH}_{70} \mathrm{~N}_{15} \mathrm{O}_{22} \mathrm{P}_{2} \mathrm{~S}\right]=1363.40\right), 1375.24$ $\left([2 \mathrm{M}+\mathrm{Na}-2 \mathrm{H}]^{2-}\left[\mathrm{C}_{104}{ }^{13} \mathrm{C}_{2} \mathrm{H}_{140} \mathrm{~N}_{30} \mathrm{O}_{44} \mathrm{P}_{4} \mathrm{~S}_{2} \mathrm{Na}\right]=1375.20\right), 1385.73\left([\mathrm{M}-2 \mathrm{H}+\mathrm{Na}]^{-}\right.$ $\left.\left[\mathrm{C}_{52}{ }^{13} \mathrm{C} \mathrm{H}_{69} \mathrm{~N}_{15} \mathrm{O}_{22} \mathrm{P}_{2} \mathrm{SNa}\right]=1386.40\right)$ with an extremely abundant peak at $170.7 \mathrm{ppm}$ in ${ }^{13} \mathrm{C}$ NMR.

\section{Supplementary Material}

Refer to Web version on PubMed Central for supplementary material.

\section{Acknowledgments}

We thank D. Hiller and E. Pfund for helpful discussions. This research was supported by NIH grant GM54839 to SAS. 


\section{References}

1. Zhong M, Strobel SA. Org. Lett 2006;8:55-58. [PubMed: 16381566]

2. Green R, Noller HF. Annu. Rev. Biochem 1997;66:679-716. [PubMed: 9242921]

3. (a) Sievers A, Beringer M, Rodina MV, Wolfenden R. Proc. Natl. Acad. Sci. U.S.A 2004;101:78977901. [PubMed: 15141076] (b) Schroeder GK, Wolfenden R. Biochemistry 2007;46:4037-4044. [PubMed: 17352494]

4. (a) Dorner S, Panuschka C, Schmid W, Barta A. Nucleic Acids Res 2003;31:6536-6541. [PubMed: 14602912] (b) Weinger JS, Parnell KM, Dorner S, Green R, Strobel SA. Nat. Struct. Mol. Biol 2004;11:1101-1106. [PubMed: 15475967]

5. Erlacher MD, Lang K, Wotzel B, Rieder R, Micura R, Polacek N. J. Am. Chem. Soc 2006;128:44534459. [PubMed: 16569023]

6. Huang KS, Weinger JS, Butler EB, Strobel SA. J. Am. Chem. Soc 2006;128:3108-3109. [PubMed: 16522067]

7. (a) Satterthwait AC, Jencks WP. J. Am. Chem. Soc 1974;96:7018-7703. [PubMed: 4436508] (b) Jencks WP, Gilchrist M. J. Am. Chem. Soc 1968;90:2622-2637. (c) Das GK, Bhattacharyya D, Burma DP. J. Theor. Bio 1999;200:193-205. [PubMed: 10504285] (d) Dorner S, Polacek N, Schulmeister U, Panuschk C, Barta A. Biochem. Soc. Trans 2002;30:1131-1136. [PubMed: 12440989] (e) Trobro S, Aqvist J. Proc. Natl. Acad. Sci. USA 2005;102:12395-12400. [PubMed: 16116099] (f) Changalov MM, et al. Chembiochem 2005;6:992-996. [PubMed: 15812855] (g) Rodnina MV, Beringer M, Wintermeyer W. Trends Biochem. Sci 2007;32:20-26. [PubMed: 17157507] (h) Rangelov MA, Vayssilov GN, Yomtova VM, Petkov DD. Org. Biomol. Chem 2005;3:737-744. [PubMed: 15731858] (i) Schmeing TM, Huang KS, Kitchen DE, Strobel SA, Steitz TA. Mol. Cell 2005;20:437-448.

[PubMed: 16285925] (j) Rangelov MA, Vayssilov GN, Yomtova VM, Petkov DD. J. Am. Chem. Soc 2006;128:4964-4965. [PubMed: 16608325] (k) Rodnina MV, Beringer M, Wintermeyer W. Q. Rev. Biophys 2006;39:203-225. [PubMed: 16893477]

8. Weinger JS, Strobel SA. Biochemistry 2006;45:5939-5948. [PubMed: 16681365]

9. Seila AC, Okuda K, Strobel SA. Biochemistry 2005;44:4018-4027. [PubMed: 15751978]

10. (a) Hengge AC, Hess R. J. Am. Chem. Soc 1994;116:1256-1263. (b) Marlier JF. Acc. Chem. Res 2001;34:283-290. [PubMed: 11308302]

11. Schramm VL. Methods in Enzymology 1999;308:301-355. and references therein. [PubMed: 10507010]

12. Okuda K, Seila AC, Strobel SA. Tetrahedron 2004;60:12101-12112.

13. Scaringe SA, Wincott FE, Caruthers MH. J. Am. Chem. Soc 1998;120:11820-11821.

14. Bobkova EV, Yan YP, Jordan DB, Kurilla MG, Pompliano DL. J. Biol. Chem 2003;278:9802-9807. and references therein. [PubMed: 12645571]

15. Sako M, Kawada H. J. Org. Chem 2004;69:8148-8150. [PubMed: 15527310]

16. Ariza X, Vilarrasa J. J. Org. Chem 2000;65:2827-2829. [PubMed: 10808466]

17. a Kawai R, Sugimoto J, Kataoka M, Hayakawa Y. Nucleosides, Nucleotides \& Nucleic Acids 2001;20:1047-1048. b Hayakawa Y, Kawai R, Hirata A, Sugimoto J, Kataoka M, Sakakura A, Hirose M, Noyori R. J. Am. Chem. Soc 2001;123:8165-8176. [PubMed: 11516266]

18. Follman H, Hogencamp HPC. J. Am. Chem. Soc 1970;92:671-677. [PubMed: 5411060]

19. Wnuk SF, Chowdhury SM, Garcia PI Jr. Robins MJ. J. Org. Chem 2002;67:1816-1819. [PubMed: 11895397]

20. Jiang C, Suhadolnik RJ, Baker DC. Nucleosides \&Nucleotides 1988;7:271-294.

21. (a) Pang H, Schram KH, Smith DL, Gupta SP, Townsend LB, McCloskey JA. J. Org. Chem 1982;47:3923-3932. (b) Solsten RT, McCloskey JA, Schram KH. Nucleosides Nucleotides 1982;1:57-64. (c) Schubert EM, Schram KH. J. Labelled Compd. Radiopharm 1982;19:929-935.

(d) Schwartz HM, MacCoss M, Danyluk SS. J. Am. Chem. Soc 1983;105:5901-5911. (e) Schwartz HM, MacCoss M, Danyluk SS. Magn. Reson. Chem 1985;23:885-894.

22. Zhong M, Robins MJ. J. Org. Chem 2006;71:8901-8906. [PubMed: 17081021]

23. Serebryany V, Beigelman L. Nucleosides, Nucleotides \& Nucleic Acids 2003;22:1007-1009.

24. Wong CH, Whitesides GW. J. Am. Chem. Soc 1983;105:5012-5014. 
25. Yamamoto DM, Upson DA, Linn DK, Hruby VJ. J. Am. Chem. Soc 1977;99:1564-1570. [PubMed: 839004]

26. Fujihara H, Schowen R. J. Org. Chem 1984;49:2819-2820.

27. Demko ZP, Sharpless KB. Org. Lett 2002;4:2525-2527. [PubMed: 12123367]

28. Spero DM, Kapadia SR. J. Org. Chem 1996;61:7398-7401. [PubMed: 11667666]

29. Stawinski J, Hozumi T, Narang SA, Bahl CP, Wu R. Nucleic Acids Res 1977;4:353-371. [PubMed: 190591]

30. a Kumar G, Celewicz L, Chlàdek S. J. Org. Chem 1982;47:634-644. b Happ E, Scalfi-Happ C, Chlàdek S. J. Org. Chem 1987;52:5387-5391. c Hagen M, Chlàdek S. J. Org. Chem 1989;54:3189_ 3195. d Hagen M, Scalfi-Happ C, Happ E, Chlàdek S. J. Org. Chem 1988;53:5040-5045.

31. Zhong M, Nowak I, Robins MJ. J. Org. Chem 2006;71:7773-7779. [PubMed: 16995685] 


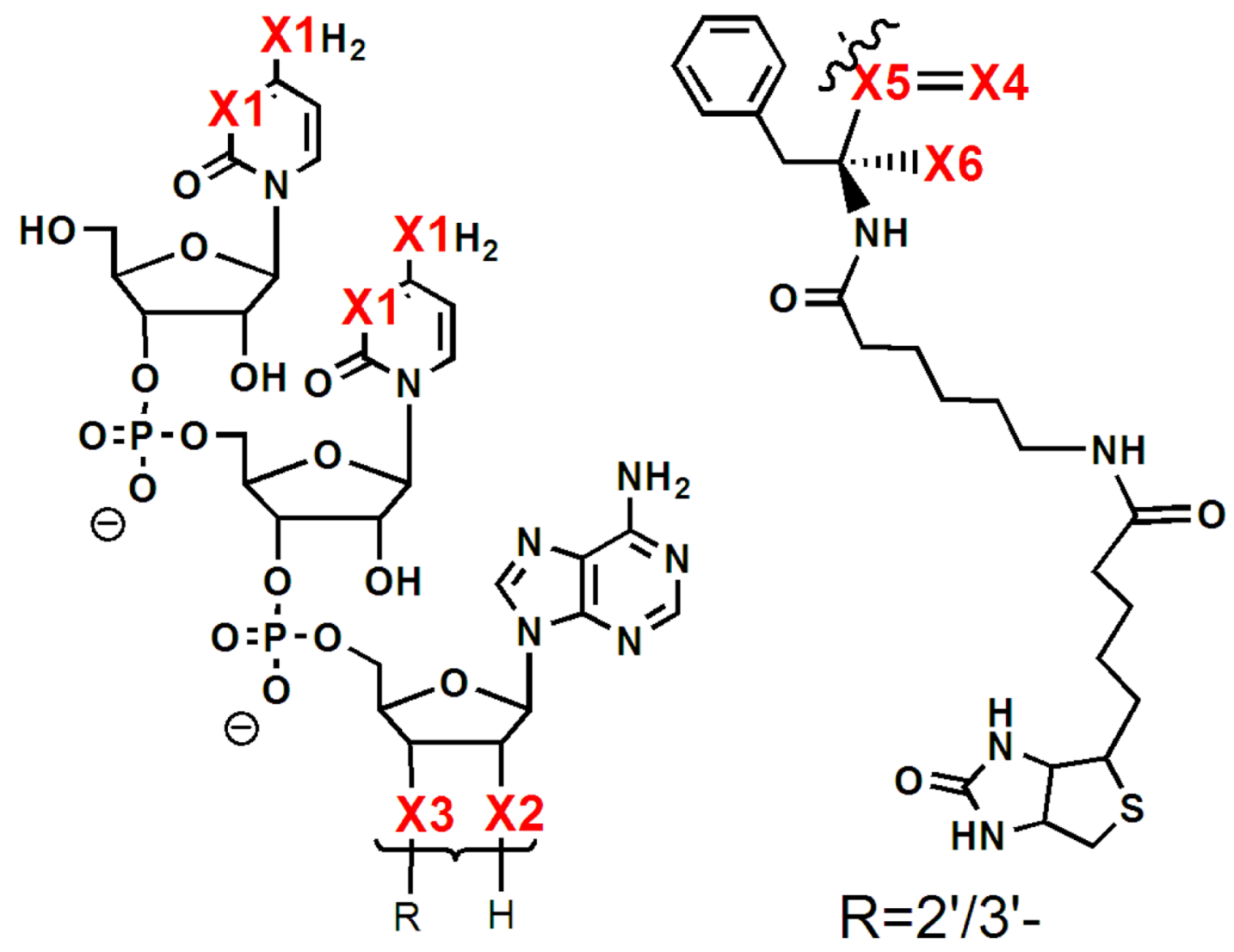

1a $\quad X 1=\mathrm{N} \quad \mathrm{X} 2=\mathrm{O} \quad \mathrm{X} 3=\mathrm{O} \quad \mathrm{X} 4=\mathrm{O} \times 5=\mathrm{C} \times 6=\mathrm{H}$

1b $\quad X 1={ }^{15} \mathrm{~N} \quad X 2=0 \quad X 3=0 \quad X 4=0 \times 5=\mathrm{C} \times 6=\mathrm{H}$

1c $X 1={ }^{15} \mathrm{~N} \times 2=0 \quad X 3=0 \quad X 4=0 \times 5={ }^{13} \mathrm{C} \times 6=\mathrm{H}$

1d $X 1={ }^{15} \mathrm{~N} \quad X 2=0 \quad X 3=0 \quad X 4=0 \times 5=\mathrm{C} X 6={ }^{2} \mathrm{H}$

1e $X 1=\mathrm{N} \times 2={ }^{18} \mathrm{O} \quad \mathrm{X} 3=\mathrm{O} \times 4=\mathrm{O} \times 5=\mathrm{C} \times 6=\mathrm{H}$

1f $X 1=\mathrm{N} \quad X 2=\mathrm{O} \quad X_{3}={ }^{18} \mathrm{O} \quad \times 4=\mathrm{O} \times 5=\mathrm{C} \times 6=\mathrm{H}$

1g $X 1=\mathrm{N} X 2=\mathrm{O} \quad X 3=\mathrm{O} X 4={ }^{18} \mathrm{O} \times 5=\mathrm{C} \times 6=\mathrm{H}$

1h $X 1=\mathrm{N} \times 2=\mathrm{O} \quad \mathrm{X} 3=\mathrm{O} \times 4=\mathrm{O} \times 5={ }^{13} \mathrm{C} \times 6=\mathrm{H}$

FIGURE 1.

Isotopomers of the P-site substrate for kinetic isotope effect analysis of ribosomal peptide bond formation. 

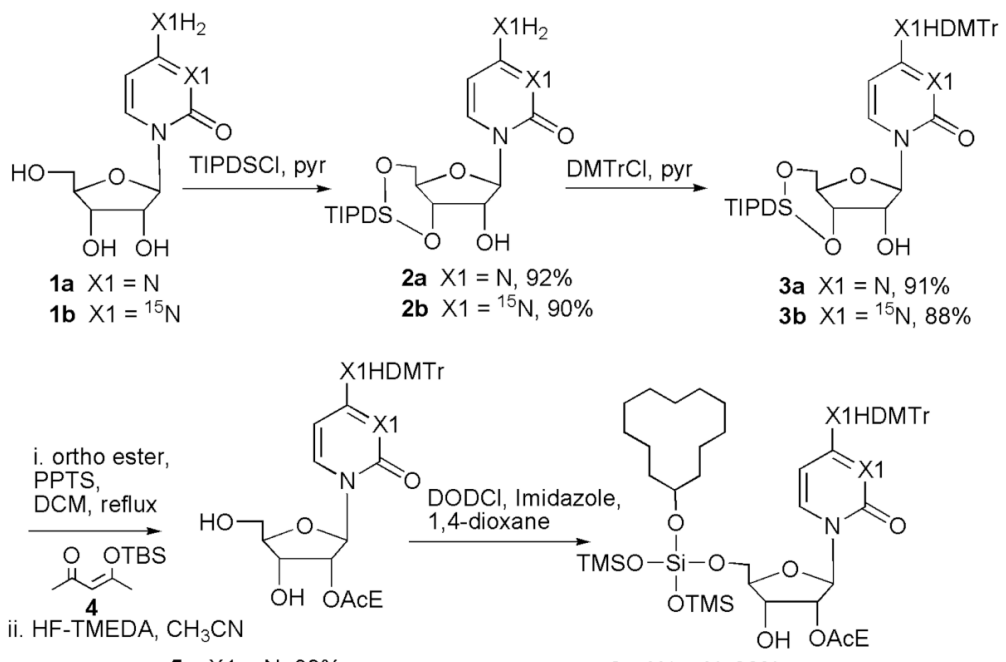

5a $X_{1}=\mathrm{N}, 89 \%$

6a $X 1=\mathrm{N}, 89 \%$

5b $\times 1={ }^{15} \mathrm{~N}, 86 \%$

6b $\times 1={ }^{15} \mathrm{~N}, 89 \%$

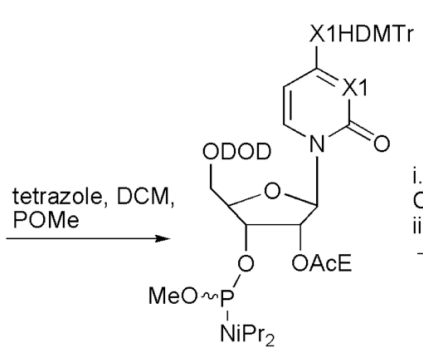

7 a $\times 1=N, 81 \%$

$7 \mathbf{b} \times 1={ }^{15} \mathrm{~N}$, quant.

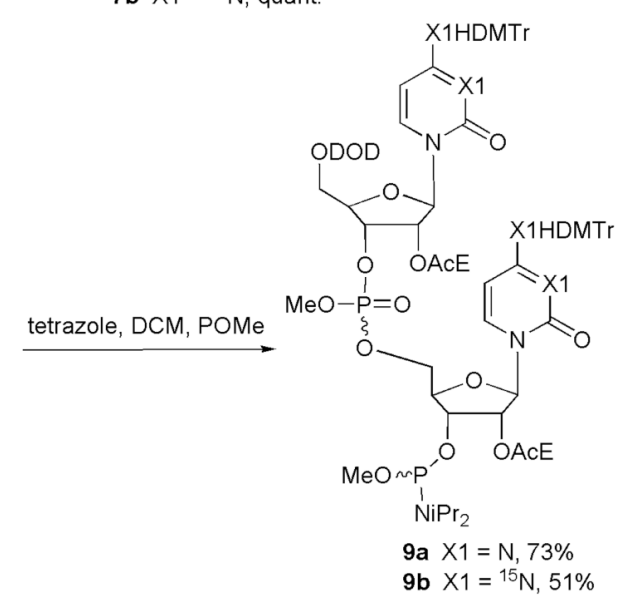

X1HDMTr

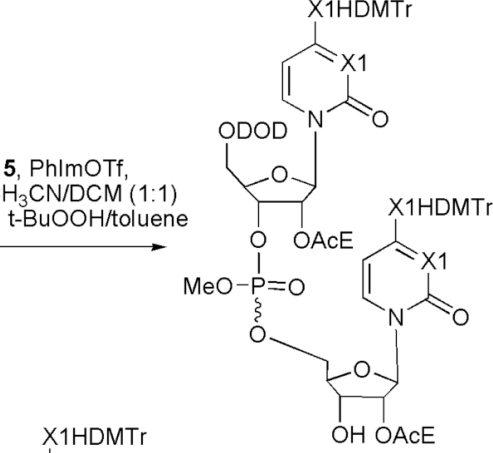

8a $\times 1=N, 81 \%$

$8 \mathrm{~b} \times 1={ }^{15} \mathrm{~N}$, quant.

9b $\times 1={ }^{15} \mathrm{~N}, 51 \%$

SCHEME 1.

Preparation of cytidinyl-(3'5')-cytidine phosphoramidite and its isotopomer 


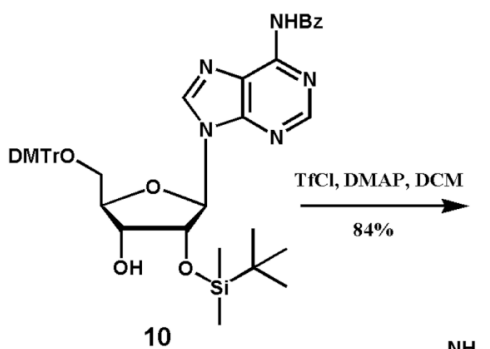<smiles>CCCCCC(C)C(C)(C)C(C)(C)C</smiles>

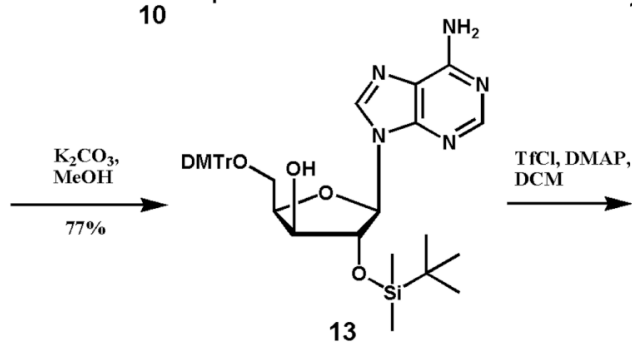

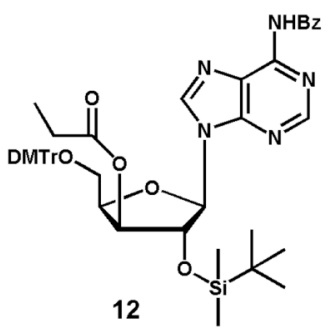<smiles>CCC(=O)OC1C(COC)OC2OCC1C2O[Si](C)(C)C(C)(C)C</smiles>

15

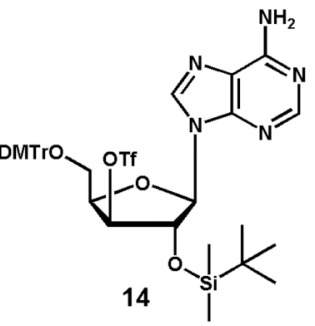

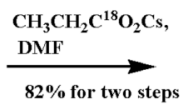

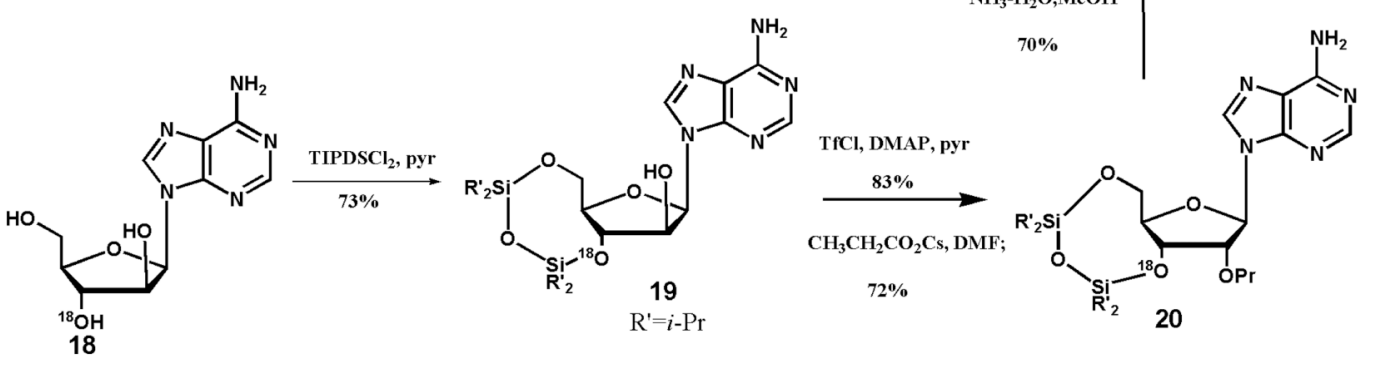

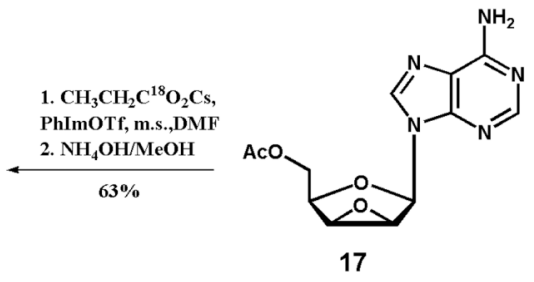

SCHEME 2.

Preparation of $\left[3^{1}-{ }^{18} \mathrm{O}\right]$ adenosine 


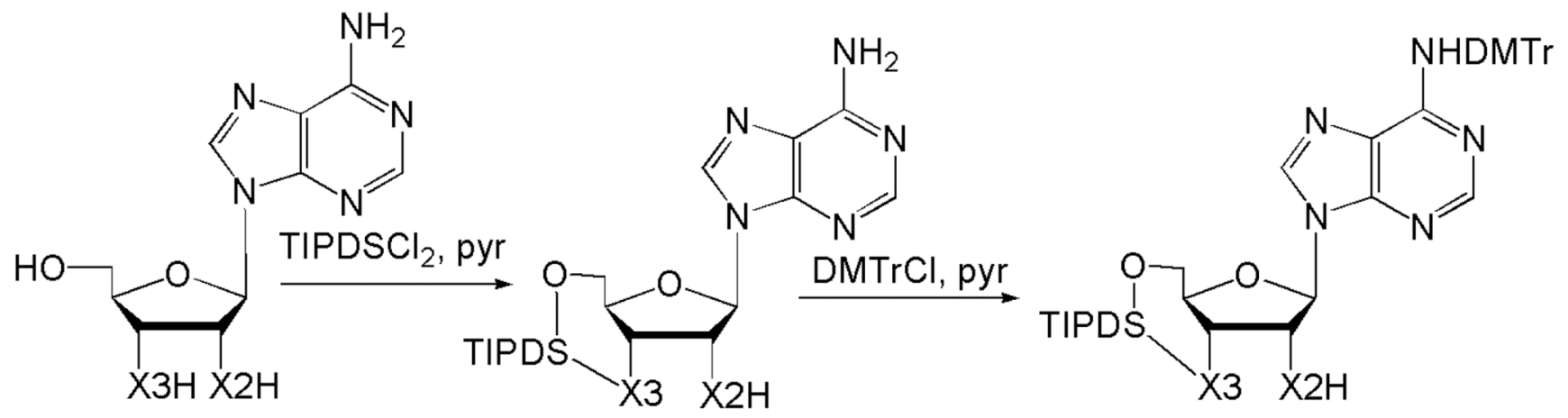

$16 \mathbf{a} \times 2=0 \times 3=0$ 21a $\times 2=0 \times 3=0,92 \%$

21e $\times 2={ }^{18} \mathrm{O} \times 3=0$

21f $\times 2=0 \times 3={ }^{18} \mathrm{O}$ 22a $\times 2=0 \times 3=0,91 \%$ 22e $\times 2={ }^{18} \mathrm{O} \times 3=0,84 \%$ 22f $X 2=0 \times 3={ }^{18} \mathrm{O}, 93 \%$

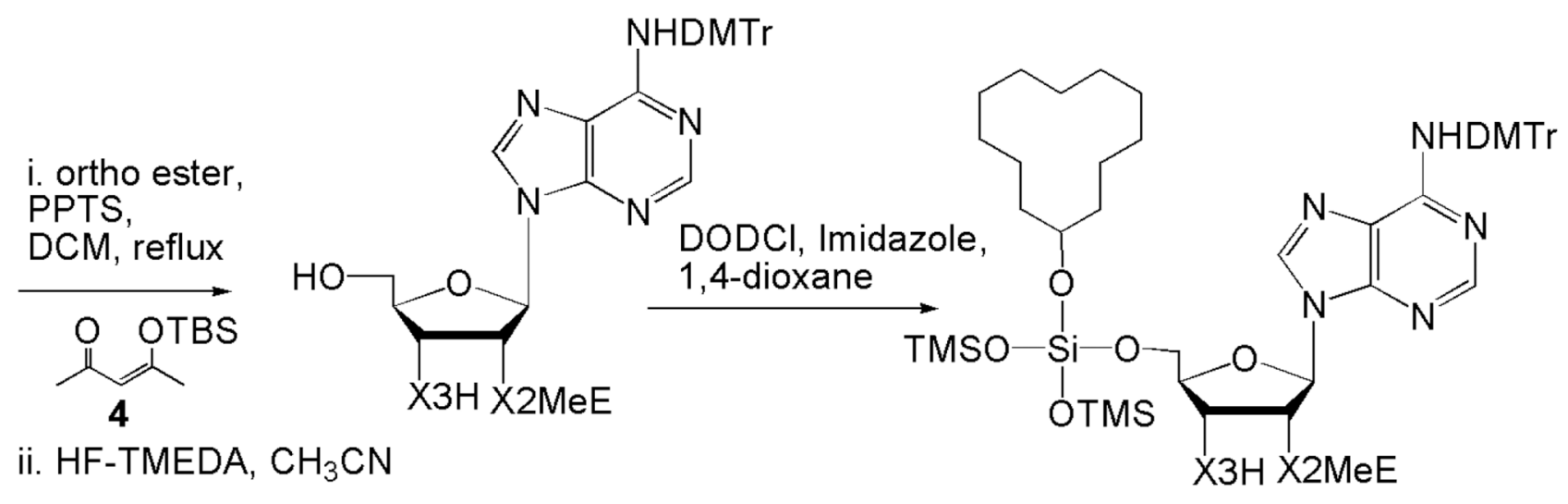

23a $\times 2=0 \times 3=0,71 \%$ 23e $\times 2={ }^{18} \mathrm{O} \times 3=0,74 \%$

$23 f \times 2=0 \times 3={ }^{18} \mathrm{O}, 70 \%$

24a $\times 2=0 \times 3=0,89 \%$

24e $\times 2={ }^{18} \mathrm{O} \times 3=0,57 \%$

24f $X 2=0 \times 3={ }^{18} \mathrm{O}, 55 \%$

SCHEME 3.

Synthesis of adenosine and $\left[2^{\prime}-{ }^{18} \mathrm{O} / 3^{\prime}-{ }^{18} \mathrm{O}\right]$ adenosine intermediates 


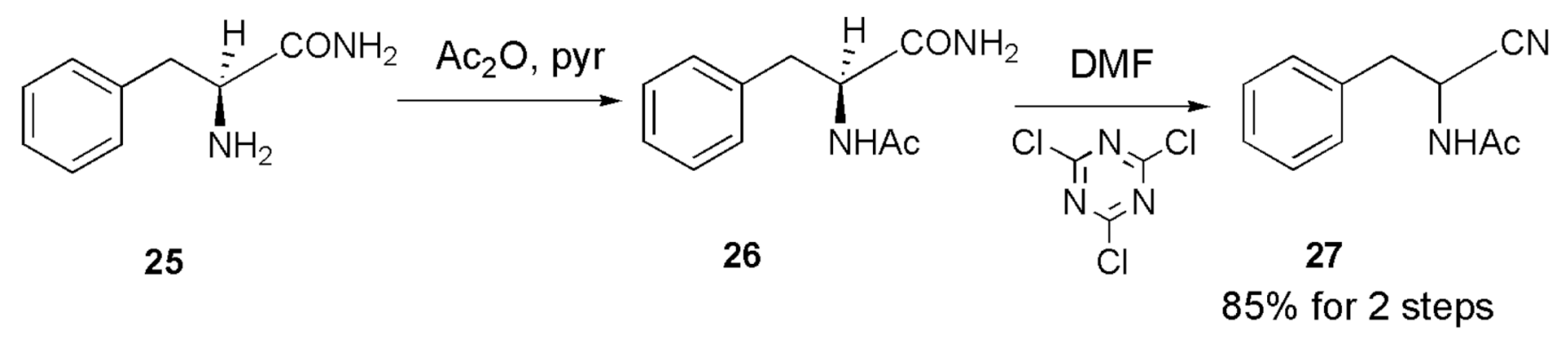

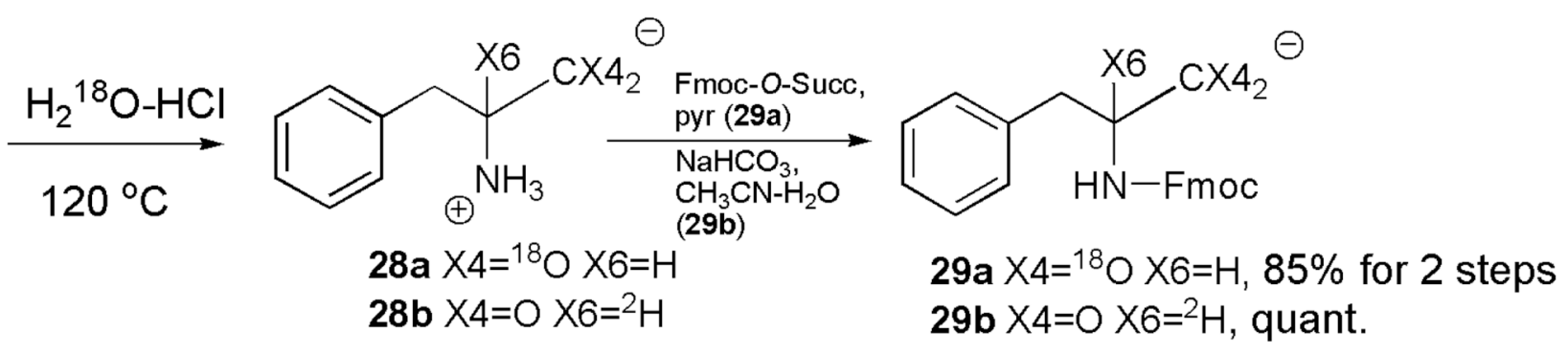

SCHEME 4.

Preparation of L- $\left[{ }^{18} \mathrm{O}_{2}\right]$-Phenylaniline 


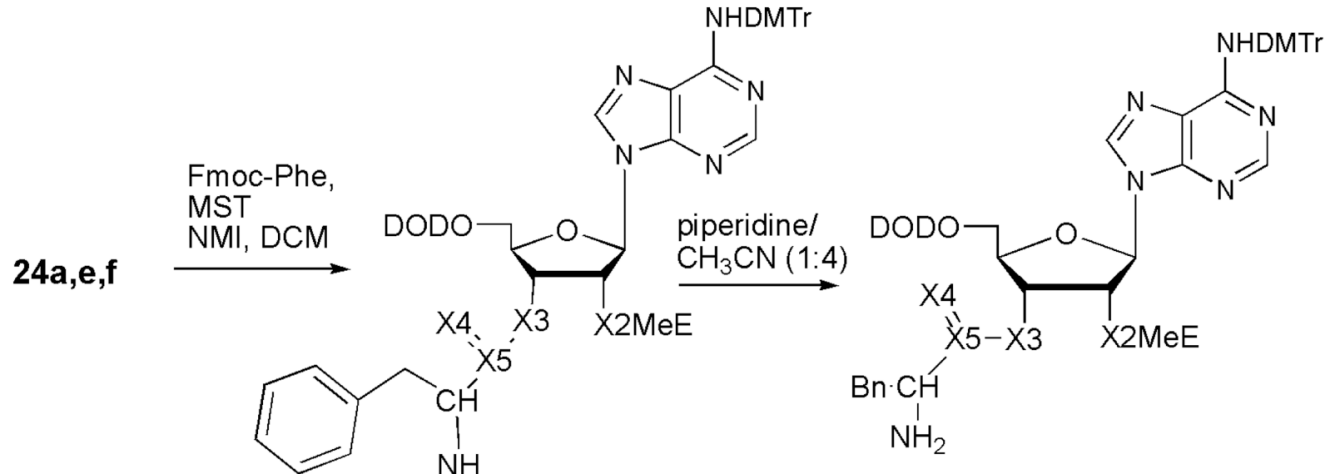

Fmoc

$30 a, d, e, f, g, h$<smiles>O=C(O)CNC(=O)CC1CCC2C1NC(=O)N2O</smiles>

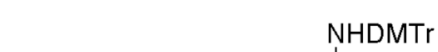

32

32, DCC,

pyr<smiles>CCCCCC1SCC2C1NC(=O)N2O[Mg]</smiles>

33a, d, e, f, g, h 31a, d, e, f, g, h

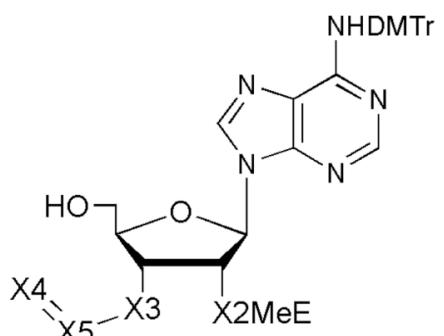
a $X 2=0 \quad X 3=0 \quad X 4=0 \times 5=\mathrm{C} X 6=\mathrm{H}$
d $X 2=0 \quad X 3=0 \quad X 4=0 \times 5=C \times 6={ }^{2} \mathrm{H}$
e $X 2={ }^{18} \mathrm{O} \quad \mathrm{X} 3=0 \quad \mathrm{X} 4=\mathrm{O} \times 5=\mathrm{C} X 6=\mathrm{H}$
f $X 2=0 \quad X 3={ }^{18} \mathrm{O} X 4=0 \times 5=\mathrm{C} X 6=\mathrm{H}$
g X2 $=0 \quad X 3=0 \quad X 4={ }^{18} O X 5=C X 6=H$
h $X 2=0 \quad X 3=0 \quad X 4=0 \times 5={ }^{13} \mathrm{C} \times 6=\mathrm{H}$

SCHEME 5.

Preparation of protected A-pcb and its isotopomers 


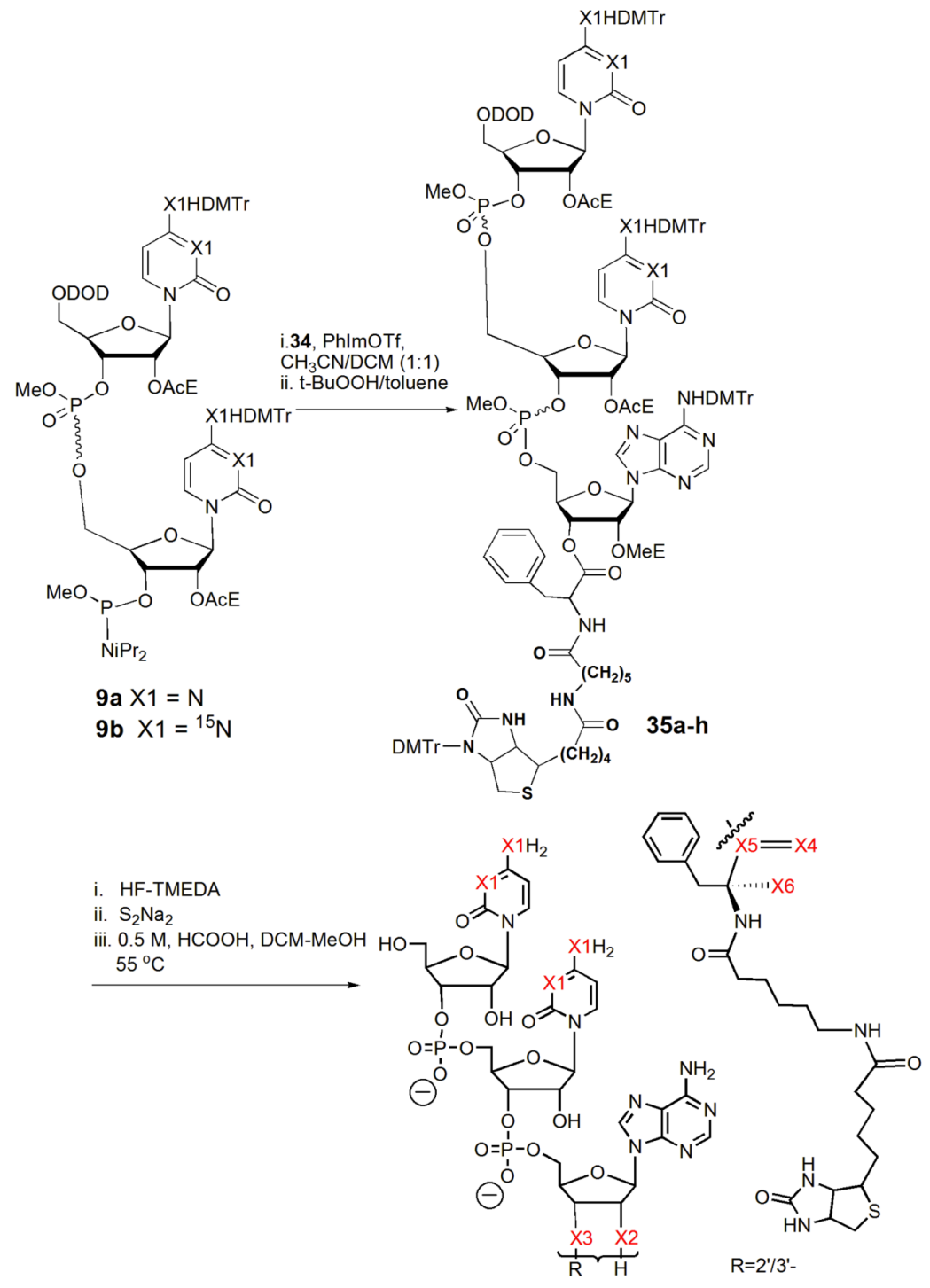

$$
\begin{aligned}
& \text { 1a } \quad \mathrm{X} 1=\mathrm{N} \quad \mathrm{X} 2=\mathrm{O} \quad \mathrm{X} 3=\mathrm{O} \quad \mathrm{X} 4=\mathrm{O} \times 5=\mathrm{C} \times 6=\mathrm{H} \\
& \text { 1b } \quad \mathrm{X} 1={ }^{15} \mathrm{~N} \times 2=\mathrm{O} \quad \mathrm{X} 3=\mathrm{O} \quad \mathrm{X} 4=\mathrm{O} \times 5=\mathrm{C} \times 6=\mathrm{H} \\
& \text { 1c } \quad X 1={ }^{15} \mathrm{~N} \quad X_{2}=\mathrm{O} \quad \mathrm{X}_{3}=\mathrm{O} \quad \mathrm{X}_{4}=\mathrm{O} \times 5={ }^{13} \mathrm{C} \times 6=\mathrm{H} \\
& \text { 1d } X 1={ }^{15} \mathrm{~N} \times 2=\mathrm{O} \quad \mathrm{X}_{3}=\mathrm{O} \quad \mathrm{X}_{4}=\mathrm{O} \times 5=\mathrm{C} \times 6={ }^{2} \mathrm{H} \\
& \text { 1e } \mathrm{X}_{1}=\mathrm{N} \quad \mathrm{X}_{2}={ }^{18} \mathrm{O} \quad \mathrm{X}_{3}=\mathrm{O} \quad \mathrm{X}_{4}=\mathrm{O} \times 5=\mathrm{C} \times 6=\mathrm{H} \\
& \text { 1f } X 1=\mathrm{N} \quad X 2=\mathrm{O} \quad \mathrm{X}_{3}={ }^{18} \mathrm{O} \quad \mathrm{X} 4=\mathrm{O} \times 5=\mathrm{C} \times 6=\mathrm{H} \\
& \text { 1g } X 1=\mathrm{N} \quad \times 2=\mathrm{O} \quad X 3=\mathrm{O} \quad \times 4={ }^{18} \mathrm{O} \times 5=\mathrm{C} \times 6=\mathrm{H} \\
& \text { 1h } X 1=N \quad X 2=O \quad X 3=O \quad X 4=O X 5={ }^{13} \mathrm{C} \times 6=H
\end{aligned}
$$

SCHEME 6.

Coupling and deprotection for CCA-pcb and its isotopomers 